\title{
Proximal to distal grain-size distribution of basin-floor lobes: A study from the Battfjellet Formation, Central Tertiary Basin, Svalbard
}

\author{
Yvonne T. Spychala ${ }^{1}$ \\ Sten-Andreas Grundvåg ${ }^{2}$ \\ Thymen A. B. Ramaaker ${ }^{1} \quad$ Joris T. Eggenhuisen ${ }^{1}$ \\ Florian Pohl $^{1}$ | Sara Wróblewska ${ }^{3}$
}

${ }^{1}$ Department of Earth Science, Utrecht University, Utrecht, The Netherlands

${ }^{2}$ Department of Geosciences, UiT - The Arctic University of Norway, Tromsø, Norway

${ }^{3}$ Faculty of Geology, University of Warsaw, Warsaw, Poland

\section{Correspondence}

Yvonne T. Spychala, Department of Earth Science, Utrecht University, 3584 CB, Utrecht, The Netherlands.

Email: spychala@geowi.uni-hannover.de

\section{Present address}

Yvonne T. Spychala, Institute of Geology, Leibniz University Hannover, Callinstr. 30, Hannover, 30167, Germany

Pohl Pohl, Marine School of Biological and Marine Sciences, University of Plymouth, Drake Circus, Plymouth, PL4 8AA, UK

\section{Funding information}

Norges Forskningsråd, Grant/Award Number: 228107; NWO, Grant/Award Number: NWO-ALW-Vidi-864.13.006; ExxonMobil; Shell Exxon Mobil Corporation; Equinor

\begin{abstract}
The grain-size distribution of sediment particles is an important aspect of the architecture of submarine fans and lobes. It governs depositional sand quality and reflects distribution of particulate organic carbon and pollutants. Documenting the grain-size distribution of these deep-marine sedimentary bodies can also offer us an insight into the flows that deposited them. Submarine lobes are commonly assumed to linearly fine from an apex, meaning there should be a proportional relationship between grain size and distance from the lobe apex. However, not much detailed quantitative work has been done to test this hypothesis. Exposure of a $5 \mathrm{~km}$ long dip-section of basin-floor lobes in Clinoform 12, Battfjellet Formation, Spitsbergen, enable the study of basinward grain-size evolution in lobe deposits. Furthermore, the dataset allows testing if there are any documentable grain-size differences between lobe sub-environments. For this purpose, the palaeogeography of Clinoform 12 was reconstructed and the youngest lobe, which was exposed in all collected logs, chosen to be evaluated for its grain-size trends. Photographed thin sections of 66 rock samples were analysed to obtain quantitative grain-size distributions. The results show that fining of lobe deposits occurs predominantly in the most proximal and most distal parts of the lobe, while the intermediate lobe, which is dominated by lobe off-axis deposits, is characterised by a relatively consistent grain-size range. Lobe subenvironments show statistically distinct grain-size distributions from lobe axis to lobe fringe. An explanation for these trends is the interplay of capacity and competence-driven deposition with the grain-size stratification of the flows. The outcomes of this study help to better understand the proximal to distal evolution of turbidity currents and their depositional patterns. They also provide important insights in reservoir potential of basin-floor fans at lobe scale.
\end{abstract}

\section{K E Y W O R D S}

flow processes, grain-size counting, palaeo-reconstruction, thin sections, turbidites

This is an open access article under the terms of the Creative Commons Attribution License, which permits use, distribution and reproduction in any medium, provided 


\section{1 | INTRODUCTION}

Grain-size distribution is one of the fundamental attributes of facies properties. It reflects transport history and depositional mechanisms of sedimentary deposits. Fine-grained turbidite systems are characterised by larger depositional systems, longer run-out distances and larger flow sizes compared to coarse-grained systems (Bouma, 2000; Reading \& Richards, 1994). Grain-size distribution of deep-marine bodies not only govern deposit characteristics like porosity and permeability (Porten et al., 2016), but is also thought to be associated with the distribution of organic carbon (Burdige, 2005; Hedges et al., 1997) and pollutants such as plastics (Kane \& Clare, 2019; Pohl et al., 2020). However, the processes that control the grain-size distribution across submarine fans are poorly understood. The root of this poor understanding seems to stem at least in part from the paucity of documentation of quantitative grain-size distribution in natural submarine fan deposits (Bell et al., 2018; Fildani et al., 2018; Kane et al., 2017).

Recent studies (de Leeuw et al., 2018a, 2018b; Jobe et al., 2017; Paolo \& Martin, 2012; Straub et al., 2012) show that grain sizes change continuously over deep-marine turbidite systems through partitioning along channel-levee complexes. This grain-size partitioning governs the range of grain sizes that is transferred to basin-floor lobe complexes (de Leeuw et al., 2018a, 2018b). In general, studies suggest that the largest amount of sand within a shelf-slope-basin floor system is located within the basin-floor deposits (Bell et al., 2018; Hubbard et al., 2014; van der Merwe et al., 2014; Prather et al., 2017), and that lobe deposits are also relatively coarse compared to the correlative channel-levee deposits (de Leeuw et al., 2018a, 2018b). The fact that basin-floor deposits are coarser grained than their coeval channel-levee deposits is explained by the stratification of flow where fining upwards within the flow hampers the loss of coarser material from the channel through overspill while increasing the loss of finer grains.

While we understand the relationship between lobes and the rest of the deep-marine system we know very little about the grain-size distribution within the lobes themselves. Sylvester and Lowe's (2004) study of vertical fining patterns within turbidites and hybrid beds was one of the first detailed studies of grain-size distribution within lobe deposits and the processes that formed them. More recently, Fildani et al. (2018) looked into detailed vertical grain-size distributions within different bed types attributed to turbidites, hybrid beds and debrites using laser particle analysis. Their study suggests that turbidite deposits in lobes contain more silty material than estimated from visual core description alone, underlining the need for integration of macroscopic facies analysis with microscopic analysis to inform more comprehensive depositional models. Bell et al. (2018) looked into longitudinal trends of grain-size distribution within lobes from the Gerbe system (Aínsa Basin, Spain) in more detail. They observed that lobe subenvironments (lobe axis, lobe off-axis, lobe fringe and lobe distal fringe; sensu Prélat et al., 2009) show a longitudinal decrease in mean grain size from lobe axis to fringe, but could not report a specific trend. Instead, they documented that for the Gerbe system down-dip decrease in grain size between lobe axis and off-axis is minimal, whereas a more distinct decrease can be documented down-dip between lobe off-axis and fringe deposits.

The aim of this integrated outcrop and grain-size study is to assess the longitudinal trend of grain-size distribution from inferred axial to fringe lobe deposits. For this purpose, quartz-dominated sandstones preserved in the basin-floor segment of Clinothem 12 (sensu Steel \& Olsen, 2002) of the Battfjellet Formation (CTB; Central Tertiary Basin, Svalbard) at Storvola and Hyrnestabben, were used. These were previously interpreted as basin-floor fan deposits (Crabaugh \& Steel, 2004; Johannessen \& Steel, 2005; Steel \& Olsen, 2002). The specific research objectives are: (a) detailed reconstruction of facies, architecture and hierarchy of the exhumed lobe deposits, (b) analysis of grain-size differences between lobe sub-environments, and (c) assessment of the longitudinal trend of grainsize distribution of the youngest exposed lobe. The documented spatial trends in grain size within and between the lobe sub-environments provide a basis to discuss flow processes of turbidity currents flowing over and depositing lobes. Gained insights could be used in future process modelling of lobe deposits.

\section{2 | GEOLOGICAL SETTING}

The CTB is located on south-west Spitsbergen, the largest island of the Svalbard archipelago, Arctic Norway (Figure 1A). The basin formed during the Palaeocene and early Eocene contemporaneous with the formation of the West Spitsbergen Fold and Thrust Belt (WSFTB), which is located along the western edge of Spitsbergen and closely linked to the strike-slip opening of the Norwegian-Greenland Sea and later sea floor spreading (Helland-Hansen, 1990; Helland-Hansen \& Grundvåg, 2021; Kellogg, 1975; Lundin \& Dore, 2002; Müller \& Spielhagen, 1990; Steel et al., 1985). Dextral shearing and subsequent transpression/compression along the De Geer Shear Zone caused by the northward movement of Greenland resulted in crustal shortening and thrusting-up of the WSFTB (Leever et al., 2011; Müller \& Spielhagen, 1990; Myhre et al., 1982). The initial phase possibly started in the Late Cretaceous or early 

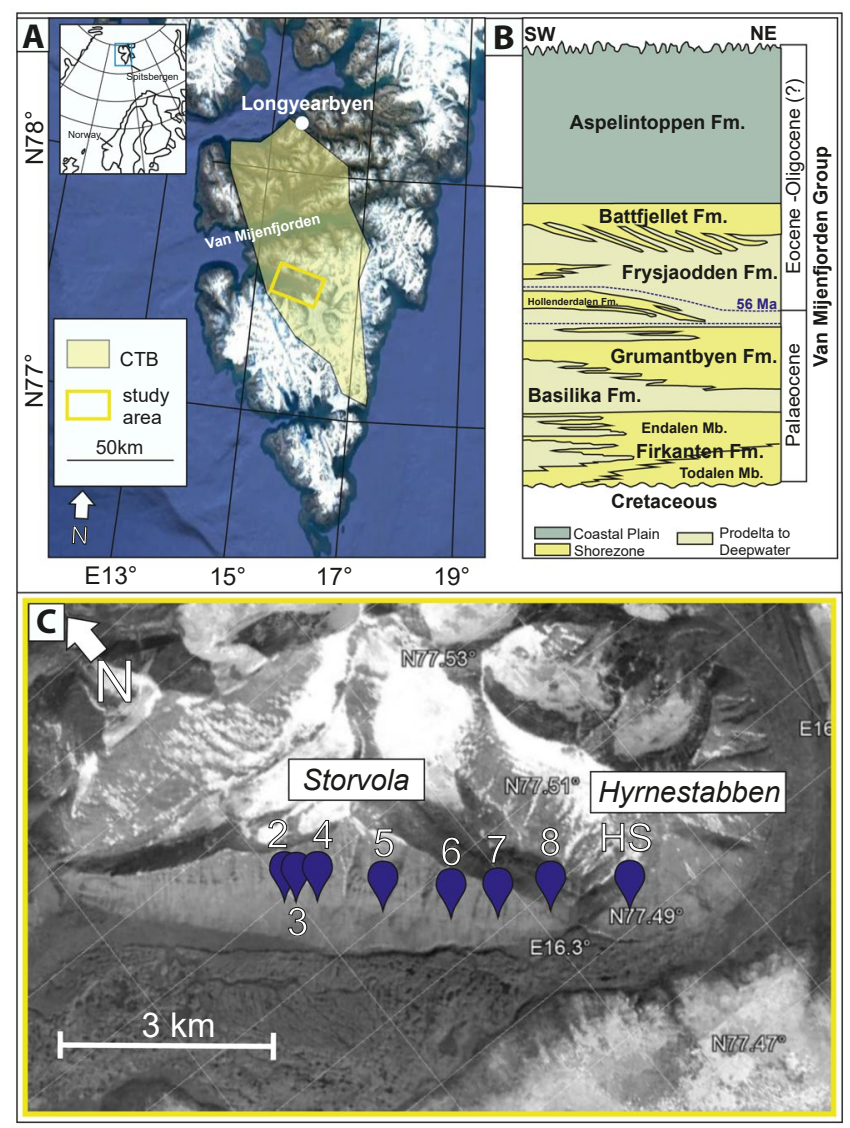

F I G U RE 1 (A) Location of the Central Tertiary Basin (CTB). The square indicates the location of the study area in the Van Keulenfjorden. (B) Stratigraphy of the CTB (modified from Crabaugh \& Steel, 2004). An Eocene to Oligocene age is interpreted for the Battfjellet Formation. (C) Location of outcrop sections along Storvola and Hyrnestabben used in the study. Satellite images are taken from Google Earth

Palaeocene with oblique contraction and possibly reversion of N-S normal faults in eastern Spitsbergen (Haremo et al., 1993) and was followed by the main phase of ENEoriented contraction during latest Palaeocene-Eocene (Bergh et al., 1997; Braathen \& Bergh, 1995; Bruhn \& Steel, 2003; Steel et al., 1985). Some authors have linked the WSFTB to the Eurekan fold belts of North Greenland and Arctic Canada (Piepjohn et al., 2016). The NNWSSE oriented CTB is located east of the orogenic belt (i.e. the WSFTB) and is identified as a foreland basin despite its connection to the bordering transpressive orogeny (Bruhn \& Steel, 2003; Helland-Hansen, 1990; HellandHansen \& Grundvåg, 2021).

The CTB comprises the ca $2.3 \mathrm{~km}$ thick Van Mijenfjorden Group, which was deposited from the early Palaeocene to the Eocene and possibly early Oligocene (Figure 1B). Sediments of the Palaeocene Firkanten, Basilika and Grumantbyen formations were delivered from the east, before a regional drainage reversal occurred at the transition from the late Palaeocene to the early
Eocene (Petersen et al., 2016; Steel et al., 1981). Subsequent formations (the Hollendardalen, Frysjaodden, Battfjellet and Aspelintoppen formations) were fed from the emerging orogenic wedge located to the west (Helland-Hansen, 1990; Petersen et al., 2016; Steel et al., 1981, 1985). This study will focus on the slope to basin-floor sediments of the Eocene Battfjellet Formation.

\section{1 | Battfjellet Formation and Clinothem 12}

The Eocene Battfjellet Formation comprises a series of clinothems that migrated eastwards into the foreland basin (Helland-Hansen, 1990, 1992; Helland-Hansen \& Grundvåg, 2021; Steel et al., 1985). Present dip angles for the associated clinoforms are in the range of $1-4^{\circ}$, and have not been decreased by more than $1^{\circ}$ by post-depositional compaction (Helland-Hansen, 1992; Plink-Björklund et al., 2001). Their amplitudes are typically reported to be in the range of 100-250 m (Helland-Hansen, 1992; Johannessen \& Steel, 2005), or more rarely up to $350 \mathrm{~m}$ (Plink-Björklund et al., 2001).

The clinothems of the Battfjellet Formation consist of shelf to slope and basin-floor deposits (HellandHansen, 1990; Mellere et al., 2002; Steel \& Olsen, 2002). Sand-prone sediments were trapped on the shelf-edge and upper slope, forming basinward-thinning wedges, or on the shelf as stacked shoreface to deltaic parasequences. (Grundvåg et al., 2014a; Johannessen \& Steel, 2005; Plink-Björklund et al., 2001). However, some clinothems show evidence of sand transport to the basin floor (Crabaugh \& Steel, 2004; Johannessen \& Steel, 2005; Plink-Björklund et al., 2001; Steel \& Olsen, 2002). Clinothem 12 is one such clinothem and is the focus of this study. The study area is part of the renowned Van Keulenfjorden transect on the south-western flanks of Storvola and Hyrnestabben, where Clinothem 12 is interpreted as representing slope and basin floor fan deposits (Clark \& Steel, 2006; Crabaugh \& Steel, 2004). The coeval shelf-delta deposits occur further to the west on the neighbouring mountain of Brogniartfjella (Johannessen \& Steel, 2005; Steel \& Olsen, 2002).

\section{3 | FIELD METHODS}

Eight stratigraphic logs, totalling $140 \mathrm{~m}$ in thickness, were collected along a $4.7 \mathrm{~km}$ transect of the exposed basin-floor fan of Clinothem 12 (Figure 1C). The logs record lithofacies, grain size (based on field observations), bed thickness, sedimentary structures, the presence of organic matter (i.e. plant debris), bounding surfaces and palaeocurrents from 
flute marks and current ripples. The stratigraphic logs comprise the exposed vertical succession of the sand-prone basin-floor fan at the outcrop locations. The heterolithic lower part of the fan is commonly weathered and covered by scree. Logs were correlated by assigning depositional sub-environments based on their lithofacies association and bounding surfaces (Prélat et al., 2009). A grain-size sample was collected every 1-2 m vertically within the individual logs near the base of the sampled beds (at about $2-3 \mathrm{~cm}$ from the base) to avoid biasing towards specific bed divisions or sedimentary structures. Sampling just above the bases of beds may under or overestimate the grain size of the entire bed as massive turbiditic sands can show inverse grading, normal grading or a lack of grading (Sylvester \& Lowe, 2004). However, most often the bed bases give a good representation of the more energetic part of the flow and the consistency is needed to compare lobe sub-environments over longer distances. Within the investigated succession, one lobe with a complete proximal to distal preservation could be recognised and only those samples (66) that are located within that lobe were selected for evaluation of the longitudinal grain-size distribution (Figures 2 and 3).



Sedimentary structures

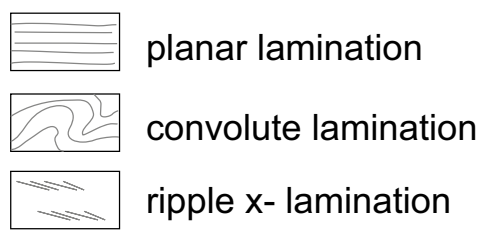

\section{Bounding surfaces}

.... amalgamation surface



Bidirectional flow indicators $(n=17)$

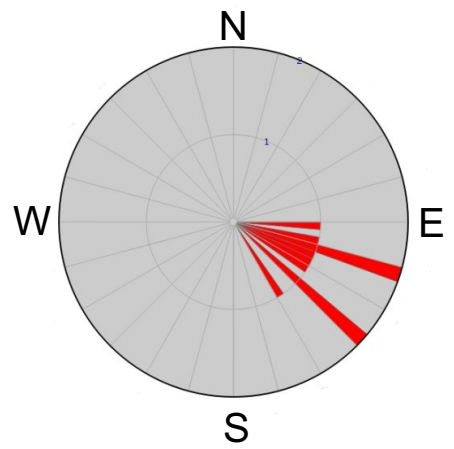

Unidirectional flow indicators $(n=10)$

F I G U RE 2 Correlation panel of Clinothem 12. Uncertain correlations are pointed out with dashed black lines. The normal fault between $\log 5$ and $\log 6$ is marked by a dark blue line. The slumped unit of the upper lobe/lobe 2 is marked by a stippled black polygon. The indicated fault between $\log 5$ and $\log 6$ is interpreted as post-depositional and serves orientation purposes only 




F I G U R E 3 Locations of samples and sample number taken within the deposits of the youngest lobe. Colours indicate the interpreted lobe sub-environment from field data alone

\section{1 | Depositional architecture of the basin floor fan}

\subsection{1 | Thickness, lithofacies and palaeoflow directions}

Clinothem 12 is formed by two sand-prone intervals that are separated by a thin-bedded heterolithic package and silt-prone package. Both sand-prone packages have an approximately $15 \mathrm{~m}$ maximum thickness. The separating heterolithic/siltstone-prone interval has a maximum thickness of $4.5 \mathrm{~m}$. The maximum exposed total thickness of $33 \mathrm{~m}$ is measured in $\log 7$ (Figure 2). Poor exposure updip of $\log 7$ prevents assessment of the total thickness in logs 2-6. In addition, the lowermost, heterolithic part of the sections is commonly scree covered, hindering accurate thickness measurements of the distal lobe fringe facies. A thinning of the clinothem can be observed distally of $\log 7$. The total thickness of the deposits thin from approximately $33 \mathrm{~m}(\log 7)$ to $13 \mathrm{~m}$ at Hyrnestabben (estimated thinning rate of $11 \mathrm{~m} / \mathrm{km}$ ). In the intermediate part of the studied section, a $4 \mathrm{~m}$ thick folded heterolithic sandstone unit can be observed at the base of the upper sand package. A detachment zone to its base suggests that part of the underlying succession may have been eroded as the deposits were remobilised.

A limited set of palaeoflow directions $(n=27)$ measured from flute marks and current ripples of Clinothem 12 deposits resulted in two different directions: 195 and $118^{\circ}$, respectively (Figure 2). Flute marks account for the southern palaeoflow indicators, while palaeoflow measurements taken from ripple laminations point to the south-east. Crabaugh and Steel (2004) reported east to south-east directed flute casts for Clinoform 12.

A bimodal flow direction in confined basins is probably caused by deflection and reflection of flow from side slopes and topographic highs (Haughton, 1994; Kneller et al., 1991; Kneller \& McCaffrey, 1999; Pohl \& McCann, 2014; Spotts, 1964). Crabaugh and Steel (2004) suggested flow diversion within the basin-floor fan of Clinoform 14 which changed from basinward to slope parallel at the most distal part and proposed that tectonically induced topography influenced fan deposition. They propose that the basin-floor fan of Clinothem 12 is not affected by such tectonic activity during sedimentation. However, influence of confinement on flow directions cannot be entirely discarded.

The main palaeoflow direction assumed from the measurements in this study is to the south-east and conforms to basinward growth of Clinothem 12 towards the southeast reported by Crabaugh and Steel (2004). The positioning of individual lobes forming the basin-floor fan is probably more variable.

\subsection{2 | Lithofacies}

Lithofacies encountered in the outcrop (Figure 4) are summarised in Table 1. Four depositional sub-environments were interpreted based on characteristic lithofacies associations: lobe axis, lobe off-axis, lobe fringe and lobe distal fringe (sensu Etienne et al., 2012; Grundvåg et al., 2014b; Prélat \& Hodgson, 2013; Marchand et al., 2015; Masalimova et al., 2016; Prélat et al., 2009; Spychala et al., 2015, 2017a) (Figure 5). 

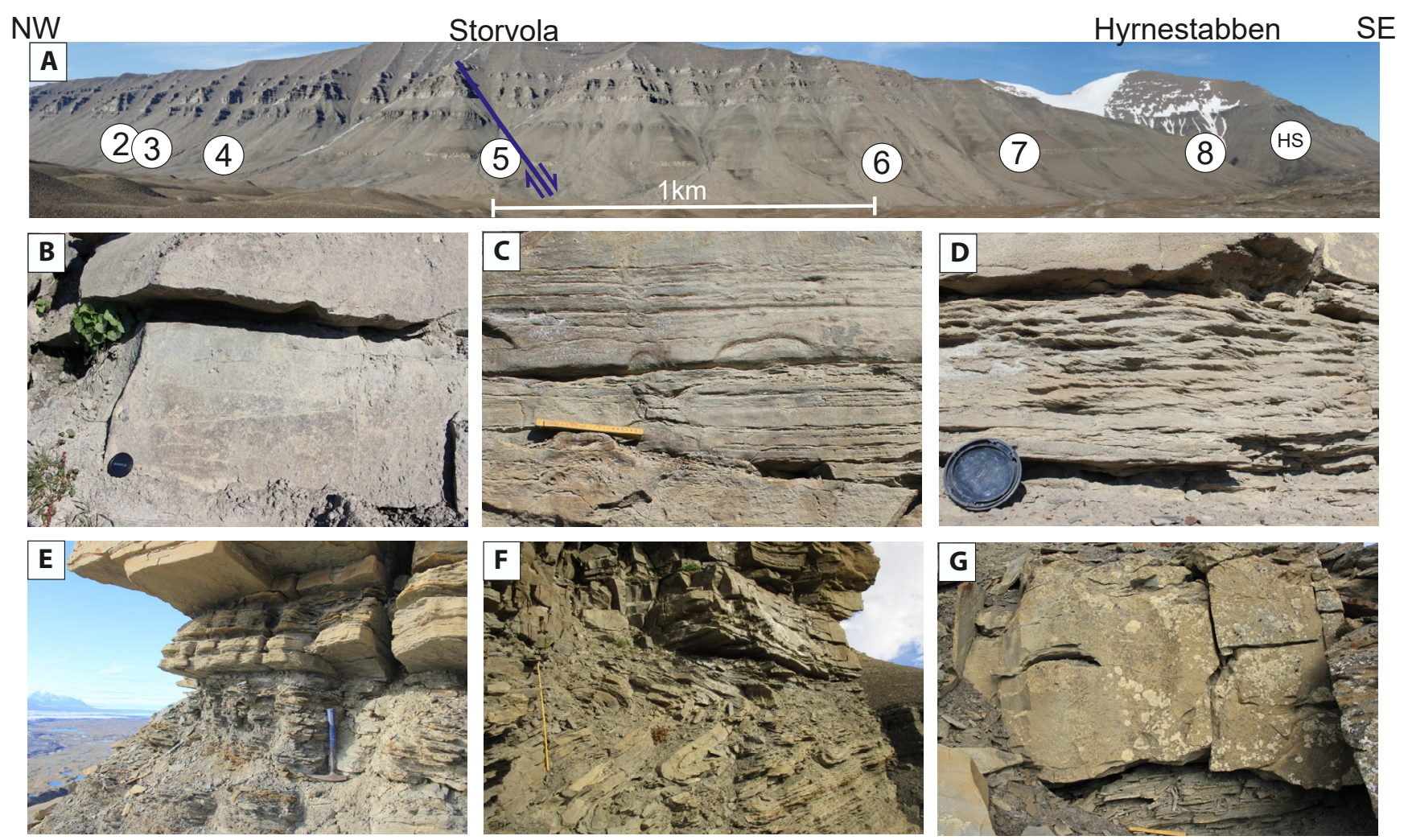

F I G U RE 4 (A) Photopanel of the study area with Storvola in the foreground and Hyrnestabben in the background to the right. Log locations are indicated with their numbers. Indicated normal fault is post-depositional and for orientation purposes only. (B) Example of F1: structureless sandstone. Lens cover as scale ( $\mathrm{ca} 7 \mathrm{~cm}$ diameter). (C) Example of F2: planar laminated sandstone. Folded rule (20 cm) as scale. (D) Example of F3: Structured sandstone. Here the deposit shows ripple laminations. Lens cover as scale (ca $7 \mathrm{~cm}$ diameter). (E) The $\log$ section at Hyrnestabben (log HS) shows F6 (siltstones) at its base which are overlain by F4 (heterolithic interval). Geological hammer $(30 \mathrm{~cm}$ ) as scale. (F) Folded sandstones at the base of the youngest lobe in the section of $\log 7$. Rule (100 cm) as scale. (G) Hybrid bed (F5) at $\log$ HS. Note the irregular transition from clean sandstone to the debritic division which is weathered back into the slope. Folded rule $(20 \mathrm{~cm})$ as scale

\section{Lobe axis}

Lobe axis deposits are comprised of thick-bedded (0.75-1.2 m) structureless sandstone (F1, Figure 4B), thin-bedded to medium bedded (0. 1-0.4 m) highly amalgamated sandstone (F1), planar laminated and stepped laminated sandstone (F2, Figure 4C). The lobe axis association is characterised by $>95 \%$ sandstone. Bed bases locally cut down up to $15 \mathrm{~cm}$ into underlying beds. Siltstones (F6, Figure 4E) are rarely observed. Amalgamation is very common and results in sandstone packages to up to $3.4 \mathrm{~m}$ thick. Deposits of the lobe axis are mostly tabular, but can also show low-relief pinching and swelling due to minor compensational stacking of beds.

\section{Lobe off-axis}

Lobe off-axis deposits are dominated by planar laminated sandstone (F2, Figure 4C), structured sandstone (F3, Figure 4D) and subordinated structureless sandstone (F1, Figure 4B). Siltstone deposits (F6, Figure 4E) separating individual sand beds are more common than in the lobe axis. This facies association is characterised by $82 \%-100 \%$ sandstone. Deposits are mostly thin-bedded to medium bedded (0.1-0.5 m), but occasionally thicker beds are present. Beds are tabular and can be traced for several tens of metres across the extent of the studied outcrop segments.

\section{Lobe fringe}

Lobe fringe deposits comprise planar laminated sandstone (F2, Figure 4C), structured sandstone (F3, Figure 4D), heterolithic packages (F4, Figure 4E), hybrid beds (F5, Figure 4G) and siltstone (F6, Figure 4E). From all the facies associations, the lobe fringe facies association is the most variable in facies and bed thicknesses, which range from thin-bedded to thick-bedded (0.05$1.1 \mathrm{~m})$. Lobe fringe deposits are characterised by $<70 \%$ sandstone. The transition of lobe fringe to distal lobe fringe is marked by the change from variable thickness packages to thin-bedded intervals with very low sand percentages $(<20 \%)$. 
TA B LE 1 Observed lithofacies in Clinothem 12, their processes and depositional environment

\begin{tabular}{|c|c|c|c|c|c|}
\hline Lithofacies & $\begin{array}{l}\text { Grain } \\
\text { size }\end{array}$ & $\begin{array}{l}\text { Thickness } \\
\text { range }\end{array}$ & Description & Process interpretation & $\begin{array}{l}\text { Depositional } \\
\text { environment }\end{array}$ \\
\hline $\begin{array}{l}\text { Structureless } \\
\text { sandstone } \\
\text { (F1) }\end{array}$ & fs to $\mathrm{ms}$ & $0.25-1 \mathrm{~m}$ & $\begin{array}{l}\text { Ungraded to graded; top can show } \\
\text { (a) a silty cap, and/or (b) coal } \\
\text { fragments (occurrence increases } \\
\text { from CF12-3 to CF12-7); bases } \\
\text { are sharp or loaded; often groove } \\
\text { and flute casts on base; outsized } \\
\text { clasts of up to } 3 \mathrm{~mm} \text {; dewatering } \\
\text { structures; mudclasts (1-2 cm) } \\
\text { at discrete horizons; up to } 3.4 \mathrm{~m} \\
\text { thick in highly amalgamated } \\
\text { intervals; } 10-15 \mathrm{~cm} \text { of erosion can } \\
\text { occur at the base }\end{array}$ & $\begin{array}{l}\text { Deposited by high-density turbidity } \\
\text { currents (Kneller \& Branney, } \\
\text { 1995) with high aggradation } \\
\text { rates (Arnott \& Hand, 1989; } \\
\text { Leclair \& Arnott, 2005; Talling } \\
\text { et al., 2012) }\end{array}$ & Lobe axis \\
\hline $\begin{array}{l}\text { Structured } \\
\text { sandstone } \\
\text { (F3) }\end{array}$ & vfs to fs & $0.05-0.25 \mathrm{~m}$ & $\begin{array}{l}\text { Wavy to sinusoidal lamination; } \\
\text { ripple cross-lamination; } \\
\text { isolated ripples; climbing-ripple } \\
\text { lamination; stratified laminations; } \\
\text { flame structures; horizontal } \\
\text { bioturbation; bed bases and tops } \\
\text { are commonly sharp and flat }\end{array}$ & $\begin{array}{l}\text { Deposited by low-density turbidity } \\
\text { currents. Wavy or sinusoidal } \\
\text { lamination indicates deposition } \\
\text { from waning currents with very } \\
\text { high rates of suspension fallout } \\
\text { (Allen, 1973; Jopling \& Walker, } \\
\text { 1968; Hunter, 1977). Current- } \\
\text { ripple lamination produced by } \\
\text { reworking through dilute flows } \\
\text { along the bed (Allen, 1982; Best } \\
\text { \& Bridge 1992; Southard, 1991). } \\
\text { Climbing ripple lamination } \\
\text { forms under bedload transport } \\
\text { associated with high aggradation } \\
\text { rates (Allen, 1973; Hunter, 1977; } \\
\text { Jobe et al., 2012) }\end{array}$ & Lobe off-axis \\
\hline
\end{tabular}

$\begin{array}{cccc}\begin{array}{c}\text { Heterolithic } \\
\text { package }\end{array} & \text { Silt and } & 0.2-0.5 \mathrm{~m} & \text { (a) Lenticular sandstone bodies } \\
\text { (F4) } & \text { vf } & \text { intervals } & \text { in siltstone, (b) intercalated } \\
& & & \text { tabular vfs and siltstone, or (c) } \\
& & \text { dominantly siltsone }(70-90 \%) \text { with } \\
& & \text { minor sandy beds }(2-5 \mathrm{~cm} \text { thick); } \\
& & \text { sandstone beds can show planar, } \\
& & \text { ripple or wavy lamination }\end{array}$

Bipartite beds csilt to fs $\quad 0.15-1.2 \mathrm{~m} \quad$ Lower sandstone division, usually (F5) structureless, rip-up clasts (up
Deposits of distal, sluggish, lowvolume flows (cf. Jobe et al., 2012). Ripple lamination forms beneath dilute turbulent flows via reworking of the bed under moderate aggradation rates, whereas climbing-ripple lamination forms under high aggradation rates (Allen, 1971, 1982; Southard, 1991)

Co-genetic turbidity currents (lower Lobe fringe division) and cohesive debris flows (upper divisions)—hybrid beds sensu Haughton et al. (2003), Talling et al. (2004), Haughton et al. (2009) and Hodgson (2009)

Lobe fringe to $30 \mathrm{~cm}$ ) on discrete horizons; upper muddier matrix with abundance of mudchips and coal fragments; poorly sorted; can be slightly graded at their tops 
TABLE 1 (Continued)

\begin{tabular}{|c|c|c|c|c|c|}
\hline Lithofacies & $\begin{array}{l}\text { Grain } \\
\text { size }\end{array}$ & $\begin{array}{l}\text { Thickness } \\
\text { range }\end{array}$ & Description & Process interpretation & $\begin{array}{l}\text { Depositional } \\
\text { environment }\end{array}$ \\
\hline Siltstone (F6) & $\begin{array}{l}\text { fsilt to } \\
\text { csilt }\end{array}$ & $0.01-0.02 \mathrm{~m}$ & $\begin{array}{l}\text { Planar bedded siltstone; mostly } \\
\text { structureless; some beds show } \\
\text { faint lamination }\end{array}$ & $\begin{array}{l}\text { Deposited by dilute turbidity } \\
\text { currents. Planar lamination is } \\
\text { a product of traction (Mutti, } \\
\text { 1992; Stow \& Piper, 1984; Talling } \\
\text { et al. 2012). Structureless beds } \\
\text { are formed by direct suspension } \\
\text { fallout (Bouma, 1962) }\end{array}$ & $\begin{array}{l}\text { Distal lobe fringe } \\
\text { to background } \\
\text { sedimentation }\end{array}$ \\
\hline $\begin{array}{l}\text { Folded } \\
\text { sandstone } \\
\text { (F7) }\end{array}$ & vfs to fs & $\begin{array}{l}0.55-4 \mathrm{~m} \\
\text { intervals }\end{array}$ & $\begin{array}{l}\text { Folded and overturned beds of } \\
5-15 \mathrm{~cm} \text { thickness; some ripple } \\
\text { laminated beds, but mostly } \\
\text { structureless and normal graded; } \\
\text { Bases of chaotic and folded units } \\
\text { are sharp to erosive, while bed } \\
\text { tops are sharp }\end{array}$ & $\begin{array}{l}\text { Syn-depositional deformation } \\
\text { due to remobilisation of local } \\
\text { thin-bedded stratigraphy. The } \\
\text { low amount of disaggregation } \\
\text { supports an interpretation of } \\
\text { slump deposits }\end{array}$ & $\begin{array}{l}\text { Not indicative } \\
\text { of a specific } \\
\text { environment }\end{array}$ \\
\hline
\end{tabular}

A

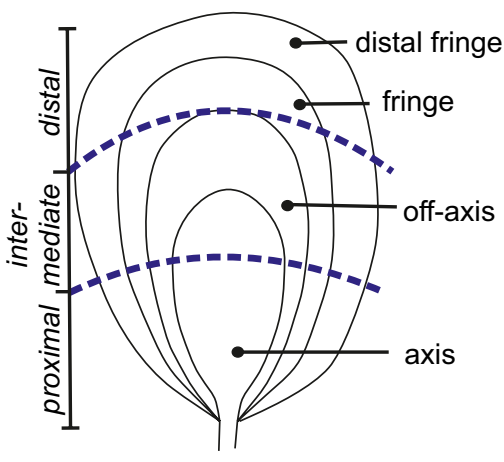

B

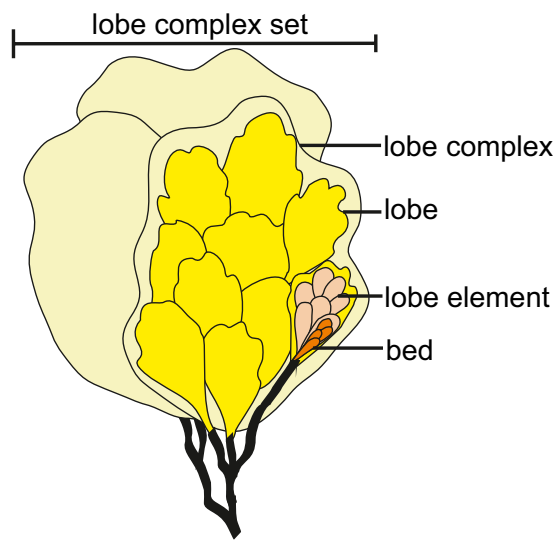

F I G U RE 5 (A) Simplified model indicating the various sub-environments in a lobe (redrawn from Prélat et al., 2009). Stippled blue lines indicate proximal, intermediate and distal lobe areas. (B) Plan-form view of fivefold lobe hierarchy: bed to bed set, lobe element, lobe, lobe complex and lobe complex set (modified from Prélat et al., 2009, redrawn from Spychala et al., 2017a)

\section{Distal lobe fringe}

Distal lobe fringe deposits are dominated by structureless and planar laminated siltstones (F6, Figure 4E). Thinbedded very fine sandstone beds can be observed to be intercalated within the silt-prone intervals. Distal lobe fringe deposit can form intervals up to $4.5 \mathrm{~m}$ thick.

\subsection{3 | Proximal and distal lobes}

The terms 'proximal', 'intermediate' and 'distal' lobe are descriptive and reference spatial areas of the deposits rather than indicating a facies-based sub-environment. These terms are not officially defined and are therefore not used consistently by different authors. Figure 5A shows the definition of these terms for this study. The proximal lobe is located up-dip, close to the feeder channel and is dominated by lobe axis deposits, but can also encompass lobe off-axis and lobe fringe deposits laterally. The intermediate lobe comprises dominantly lobe off-axis deposits, but may also comprise deposits from all other lobe sub-environments.
Geographically the intermediate lobe is neither close to the feeder channel nor to the lobe pinch-out. Finally, the distal lobe is characterised by deposits from the lobe fringe and lobe distal fringe only. It is located down-dip and marked by its association with the down-dip pinch-out of the sandy lobe deposits.

\subsection{4 | Hierarchy of Clinothem 12}

Lobe deposits commonly exhibit a fivefold hierarchy (Deptuck, 2008; Grundvåg et al., 2014b; Prélat et al., 2009; Spychala et al., 2017a): (a) a 'bed' represents a single depositional event; (b) one or more beds stack to form a 'lobe element'; (c) several lobe elements that are divided by thin siltstone intervals form a 'lobe'; (d) one or more genetically related lobes stack to form a 'lobe complex'; and (e) one or more lobe complexes within the same lowstand systems track stack to form lobe complex sets (Figure 5B). The studied section of Clinothem 12 conforms to the hierarchical level of lobe complex. The lower and upper 
sandstone-prone intervals conform to two lobes which are separated by lobe fringe deposits (thin-bedded heterolithic package), suggesting that there were genetically related sandstone-prone lobe deposits lateral to the exposed study area. Occurrence of hybrid beds in the most distal logged section at Hyrnestabben (log HS; Figure 1C) points towards the youngest lobe being exposed in a near dipsection as frontal lobes are more likely to exhibit hybrid bed deposits (Spychala et al., 2017a, 2017b). However, it cannot be excluded that the exposure may be slightly oblique to the main palaeocurrent direction.

\section{2 | Grain-size evaluation}

\subsection{1 | Procedure}

Thin sections with a thickness of $30 \mu \mathrm{m}$ were produced from 66 samples (one per sample) and these thin sections were photographed with a high-resolution camera under a Leica microscope. Samples were counted by grid counting manually outlined grains using image processing software (ImageJ) which automatically records the long and short-axis and orientation of the long-axis based on the best fitting ellipse of the grains. The grid size was kept at $0.03 \mathrm{~mm}^{2}$. Per sample 300 grains $(19,800$ grains in total) were measured to provide sufficient accuracy even for very poorly sorted sandstones (Johnson, 1994). To correct for underestimation of the spherical-grain mean values due to cutting effects, the recorded long and short-axis are multiplied by 1.1318 (Johnson, 1994). The true nominal grain diameter (the diameter of a sphere with the same volume as the considered particle) was calculated following Johnson (1994):

$$
D^{\prime}=d^{\prime}+0.4(a \prime-d \prime) 2
$$

where $D^{\prime}$ is the true nominal diameter $(\mathrm{mm})$, and $d^{\prime}=\left(a^{\prime}\right.$ $\left.b^{\prime}\right) 1 / 2$, and $a^{\prime}$ and $b^{\prime}$ are the corrected long and short-axes $(\mathrm{mm})$, respectively. True nominal grain diameters were converted to $\phi$-scale ( $\phi=-\log 2(D \mathrm{~mm})$; Krumbein, 1934) to give the most satisfactory representation of the distribution (Johnson, 1994). Determining grain size from photographed thin sections causes a lower precision for grains below the thin section thickness (de Leeuw, 2017; Johnson, 1994; Sylvester \& Lowe, 2004) as they might overlap each other. A lower limit for grain-size measurement was placed at $30 \mu \mathrm{m}$ in this study. This limit excludes fine-silt from grain-size measurements. The obtained grain-size distributions in $\phi$ are approximately normally distributed and suggest a lognormal distribution on the linear scale. Descriptive statistical measures (mean $[M]$, standard deviation $[\sigma]$, skewness $[S]$, and kurtosis $[K])$ are calculated using MATLAB.
To test the hypothesis that grain-size distributions of lobe sub-environments are statistically different an analysis of variance (ANOVA) was applied to the mean grain size of the distributions. ANOVA compares the 'variance between/among' grouped data with the 'variance within' a group. For this study the grouping will be based on lobe sub-environments: lobe axis, lobe off-axis and lobe fringe. Although grain size is a factor that plays into the assessment of lobe sub-environments, evaluation of the grain-size distribution between these 'groups' can help us determine if their transitional character is dominant or if they actually form individual clusters.

\subsection{2 | Measurement errors}

Two types of measurement error were investigated by dissecting a single sample in multiple orientations (orientation error) and counting grain sizes by multiple operators (operator error). The observed differences between groups of samples need to clearly exceed these measurement errors for the results to indicate significant differences.

\subsection{3 | Orientation error}

Non-spherical grains are frequently arranged in specific patterns with respect to the palaeoflow direction (Arnott \& Hand, 1989; Baas et al., 2007; Hiscott \& Middleton, 1980). In turbidites, a flow-aligned fabric (with the long axis aligned with the palaeoflow direction) is favoured during relatively rapid sedimentation from suspension, whereas flow-transverse fabric is the result of grain transportation along the bed by traction during relatively low sedimentation from suspension. Oblique fabric appears to be restricted to massive sandstone turbidites but the mechanism causing this fabric is still unclear (Baas et al., 2007).

For consistency, all selected samples (66) were cut perpendicular to the bedding with most samples (51) cut parallel to the assumed main palaeoflow direction of $118^{\circ}$. For some samples the orientation of the samples could not be reconstructed after returning from the field, and for other samples, the limited number of palaeoflow measurements taken from few other beds, sometimes in another stratigraphic section, could be a poor reflection of the true transport direction of that sample. These uncertainties necessitate a careful assessment of the measurement errors related to the orientation of the thin sections relative to the palaeoflow orientation. For this purpose, one sample was selected and cut parallel, perpendicular and oblique $\left(45^{\circ}\right)$ to the assumed main palaeoflow direction of $118^{\circ}$. The data show that the measured grain size indeed varies depending on the orientation of the thin 
A

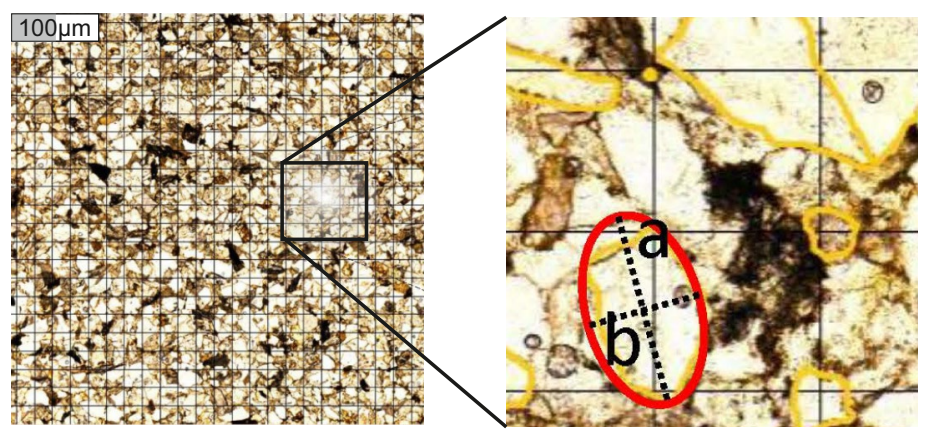

B

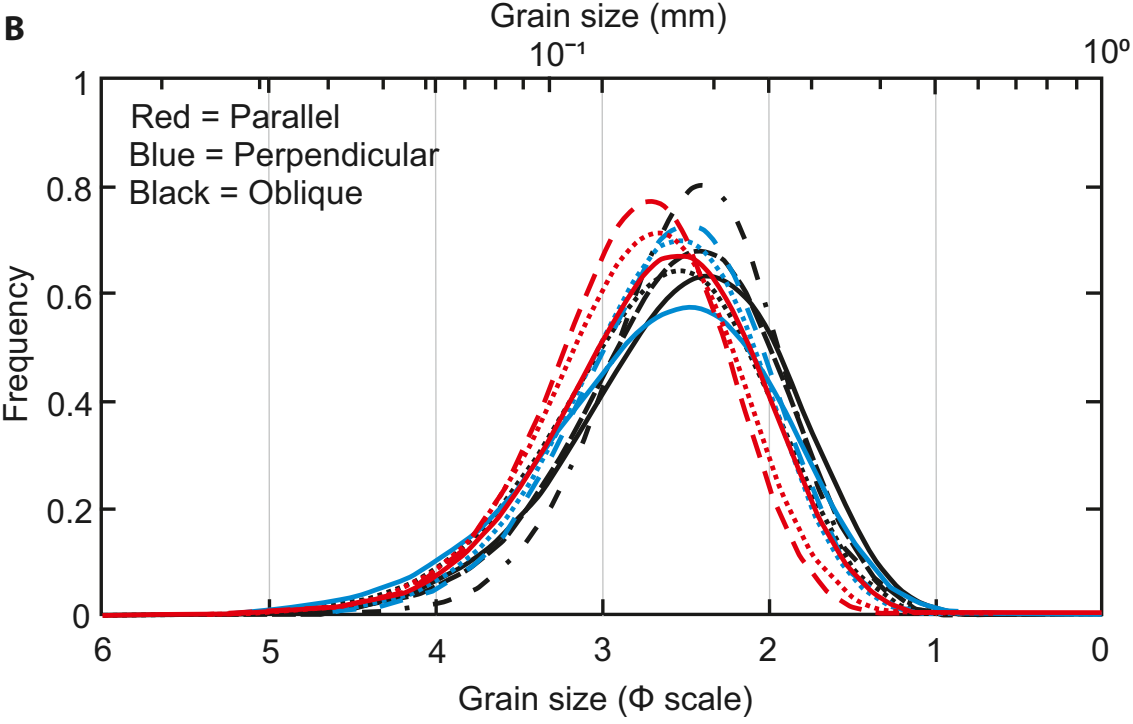

F I G URE 6 (A) Example of outlined grains processed with ImageJ. First a scale is set to create the accurate number of grid points. Second, grains are marked manually. ImageJ measures the major $\left(a_{\mathrm{mm}}\right)$ and minor $\left(b_{\mathrm{mm}}\right)$ axis. (B) Master sample grain-size evaluation: Grain-size distributions of oriented samples with respect to the palaeoflow analysed by three different operators. Each operator counted at least 300 grains. The line styles represent the operators: solid line $=$ Sara Wroblewska; loosly stippled line $=$ Yvonne Spychala; closely stippled line $=$ Thymen Ramaaker section with respect to $118^{\circ}$, which illustrates the error of cutting the sample in different orientations (Figure 6). The pooled standard deviation ('weighted average standard deviation') for different orientations of the sample is $0.06 \phi$.

\subsection{4 | Operator error}

The three thin sections of the sample were analysed by three different operators to test the effect of operatorchoices in outlining individual grains. The pooled standard deviation ('weighted average standard deviation') for the error due to individual operator choices is $0.11 \phi$. Based on this analysis, the decision was made to evaluate all samples by a single operator (T.A.B. Ramaker) to ensure consistent application of grain-delineations and avoid inter-operator errors.

\section{3 | Grain-size distribution}

Figure 7 illustrates the grain-size distributions of 19 lobe axis samples, 40 lobe off-axis samples, and seven lobe fringe samples. With the exception of a few grains,

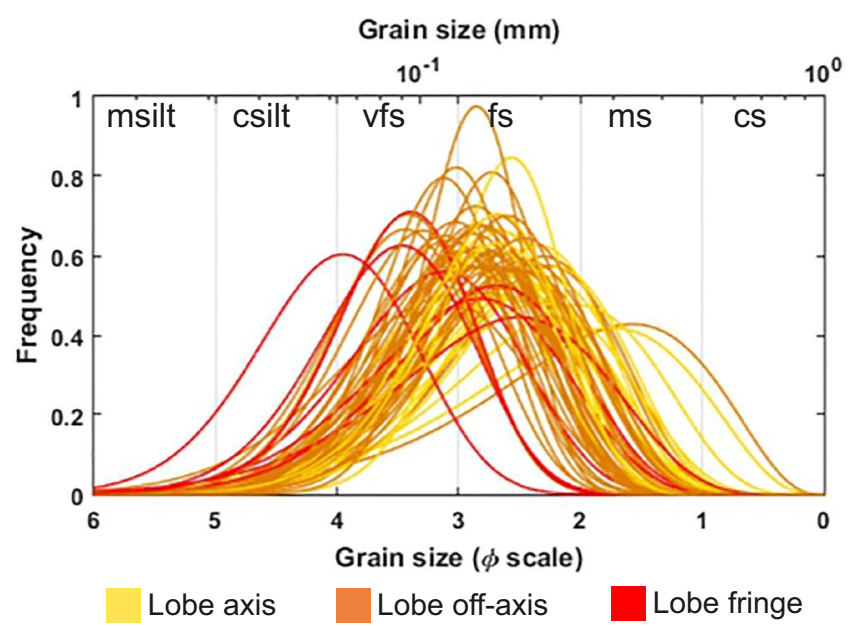

FI G URE 7 Probability density functions of the grain-size distributions of basin-floor fan deposits of Clinothem 12 showing all 66 grain-size distributions of lobe axis (yellow), off-axis (orange) and fringe (red) samples

measured individual grain sizes range from 0 to $6 \phi(1,000$ to $30 \mu \mathrm{m}$; coarse sand to medium silt). The grain-size distributions show mean grain-size values ranging from 2.06 to $4.03 \phi(239$ to $61 \mu \mathrm{m})$ with an average mean of $2.89 \phi$ 
$(134 \mu \mathrm{m})$ (standard deviation of $0.33 \phi)$. Fifty-six of the 66 samples have a mean grain size between 2.5 and $3.5 \phi$ (177 to $88 \mu \mathrm{m}$ ) with only one sample being finer than $3.5 \phi$ $(4.03 \phi)$. Modal grain size ranges from 1.57 to $3.95 \phi$ (336 to $64 \mu \mathrm{m}$ ) and indicates an overall slightly skewed distribution towards finer material (excess of finer material).

Most samples are moderately well sorted (standard deviation of $0.5-0.7 \phi)$ or moderately sorted $(\sigma: 0.7-1.0 \phi)$. The lobe off-axis samples especially are predominantly moderately well sorted. Grain-size curves of the measured samples are mainly symmetrical (skewness of -0.1 to 0.1 ) but can be fine skewed (0.1-0.3) indicating a tail of finer grains.

\section{4 $\quad$ Grain-size distribution within sub-environments}

The lobe sub-environments have similar distribution curves within each group, but show significant differences between groups. Lobe axis (Figure 8A), lobe off-axis
(Figure 7B) and lobe fringe (Figure 8C,D) have mean grain-size values of $2.68 \phi(156 \mu \mathrm{m}$; standard deviation $[\sigma(\phi)]$ of 0.20$), 2.91 \phi(133 \mu \mathrm{m} ; \sigma[\phi]: 0.29)$, and $3.30 \phi$ $(101 \mu \mathrm{m} ; \sigma[\phi]: 0.43)$, respectively. The analysis of variance (ANOVA) of the mean grain sizes indicates that all three sub-environments are statistically different at a confidence level of $99 \%$ (for detailed information see Table 2). Although the mean grain-size values are distinctly different, there is still overlap between the grain-size distribution curves which means no sub-environment has a discrete grain-size range that separates them from the other sub-environments.

Lobe axis, lobe off-axis as well as lobe fringe have samples that are fine skewed (Figure 9). No relationship between mean grain size and bed thickness (of sampled beds), standard deviation, skewness or kurtosis could be observed to be characteristic for any sub-environment.

Lobe sub-environments were defined based on lithofacies implying a possible difference in grain orientation between lithofacies associations which could affect the


F I G U R E 8 Examples of lobe sub-environment lithology and grain size in thin sections. (A) Lobe axis. Sample 6 of log 3. (B) Lobe offaxis. Sample 12 of log 5. (C) Lobe fringe. Sample 4 of log Hs. (D) Lobe fringe hybrid bed. Sample 8 of log HS 


\begin{tabular}{|c|c|c|c|c|c|}
\hline Source & $\begin{array}{l}\text { Sum-of } \\
\text { squares (SS) }\end{array}$ & $\begin{array}{l}\text { Degrees of } \\
\text { freedom }\end{array}$ & $\begin{array}{l}\text { Mean } \\
\text { squares }\end{array}$ & F-Distribution & Prob $>F$ \\
\hline Between & 2.06 & 2 & 1.03 & 12.69 & 0.00002 \\
\hline Within & 5.12 & 63 & 0.08 & & \\
\hline Total & 7.18 & 65 & & & \\
\hline
\end{tabular}

TABLE 2 One-way ANOVA table

grain-size distribution. However, the observed difference in grain-size distribution between the different cutting orientations $(0.06 \phi)$ is significantly smaller than the difference between lithofacies associations. Furthermore, the range within the sub-environments is significantly larger than the deviation caused by cutting orientation, which indicates that true variability is larger than measurement error both within sub-environments and between sub-environments.

\subsection{1 | Longitudinal trends}

A regression analyses of the mean grain size of all samples shows a moderate negative correlation $(R=-0.51)$ with distance over $5 \mathrm{~km}$ (Figure 9). However, samples with mean grain sizes coarser than $2.5 \phi(177 \mu \mathrm{m})$ are only observed in the most proximal part of the basin-floor fan. Samples with mean grain size between 2.5 and $3.5 \phi$ (177 to $88 \mu \mathrm{m}$ ) can be observed throughout the dip-section without a clear decrease in value. The finest mean grain sizes are recorded in the distal fringes of the Hyrnestabben section. Looking at longitudinal grain-size distributions of the interpreted lobe sub-environments separately a more detailed pattern can be seen. Lobe axis settings reach halfway along the exposed lobe section and show a relatively stronger correlation with distance $(R=-0.56$; Figure 10). Lobe off-axis deposits occur along the entire studied transect (more than $3.5 \mathrm{~km}$ ) with the exception of the most distal $\log$ at Hyrnestabben (Figure 1C). Samples from these off-axis deposits only show a weak decrease in mean grain size $(R=-0.23)$. For these samples no correlation between distance and any other parameter is found. Lobe fringe deposits collected from $\log 8$ and HS (Figure 2) indicate a decrease in grain size $(R=-0.42$; Figure 10$)$ over a distance of roughly $1 \mathrm{~km}$.

\subsection{2 | Vertical trends}

Vertical trends through the individual logs are illustrated in Figure 11. No absolute datum is present throughout the section to retrieve absolute vertical positions within the lobes, and each log has a different thickness. Therefore, sampled beds are imaged using equal vertical spacing between beds.
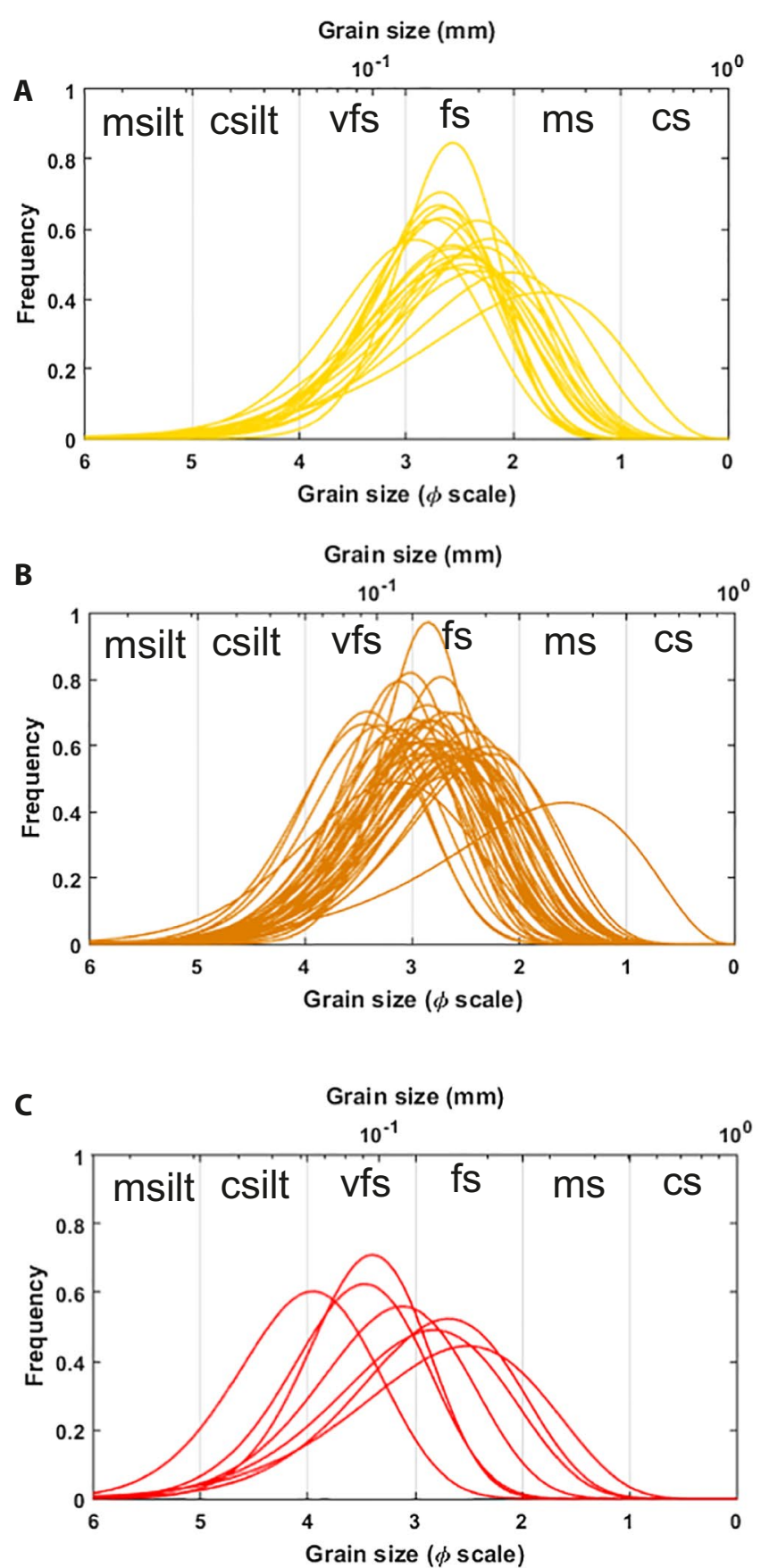

Lobe axis Lobe off-axis

\section{Lobe fringe}

FI G URE 9 Probability density functions of the grain-size distributions of lobe sub-environment deposits of Clinothem 12. (A) Lobe axis. (B) Lobe off-axis. (C) Lobe fringe 


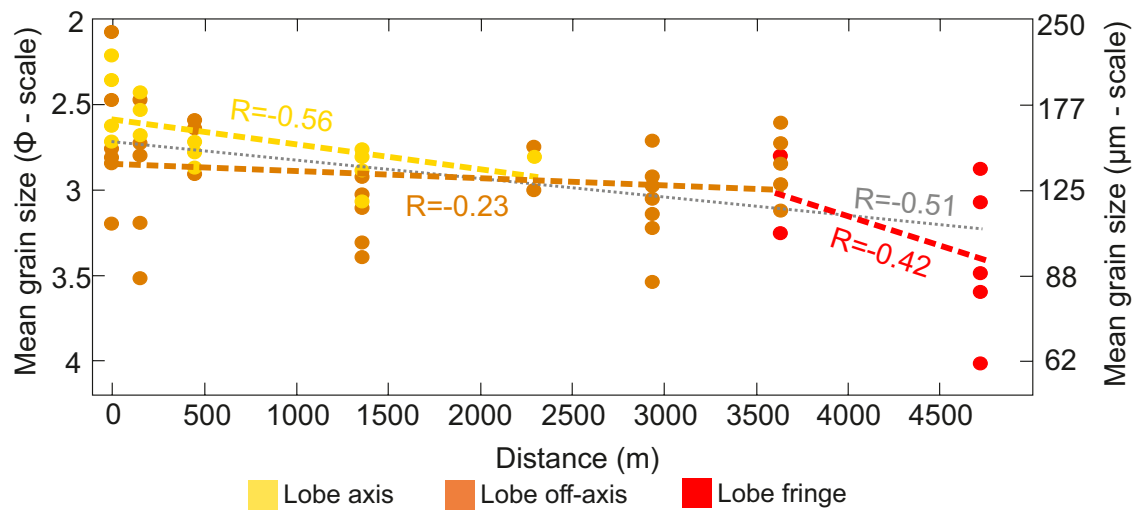

F I G U RE 10 Longitudinal development of mean grain size. Black dotted line indicates the linear regression of the mean grain size of all samples with longitudinal distance $(R=-0.51)$. Lobe axis, off-axis and fringe samples and their linear regression with distance $(R=-0.56$, $R=-0.23$, and $R=-0.42$, respectively) are indicated by the yellow, orange and red points and dotted lines, respectively. Note the relatively stable range in mean grain size of lobe off-axis samples
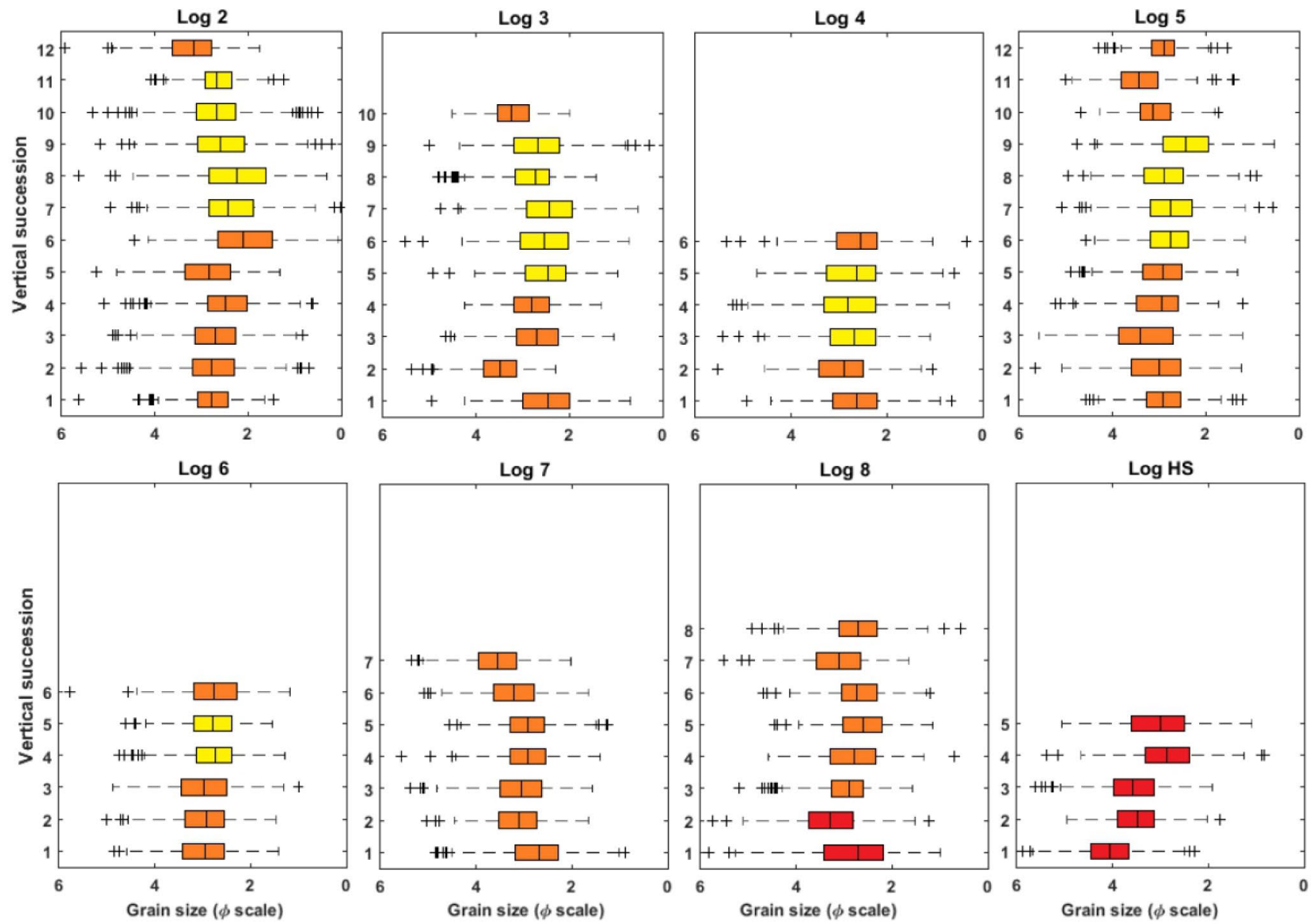

Lobe axis

Lobe off-axis

Lobe fringe

F I G U R E 11 Boxplots of grain-size distributions in vertical succession (with numbers on the y-axis referring to the order of the sampled beds from base to top) of individual logs. Colours indicate the sub-environments lobe axis (yellow), off-axis (orange) and fringe (red). The vertical line within the box indicates the median and the boundaries of the box indicate the 25th and 75th percentile. The whiskers, marked as $\mathrm{F}_{-}-$-, extend 1.5 times the interquartile distance (distance between indicate the 25 th and 75 th percentile). The plotted whiskers extend up to adjacent value that is the most extreme data point within the calculated whisker. The outlier, marked as + , are values above or below the whiskers 
No obvious overall vertical coarsening or fining trend is observed (Figure 11). Only the most distal location (log HS) that consists solely of lobe fringe deposits has a vertical coarsening trend with mean grain size shifting from 4.03 to $3.06 \phi(30-119 \mu \mathrm{m})$. Other logs appear to show a subtle coarsening to fining trend with the coarsest samples at the middle to upper part of the log. This is clearly observed in $\log 2$ where the lower six samples represent lobe off-axis and show a coarsening trend followed by five lobe axis samples that show an overall fining upwards. The lowermost samples of the logs are commonly relatively coarse. But these subtleties could be coincidence.

\section{DISCUSSION}

Clark and Steel (2006) showed that basin-floor fans of the Battfjellet Formation consist mainly (75\%) of fine sand (125-250 $\mu \mathrm{m} ; 3-2 \phi)$. Overall, this agrees with the grainsize distributions reported here, especially when considering Clark and Steel (2006) used the coarsest part of the beds to determine the grain size of the deposits. However, visual observations made in the field can neither record the range of grain sizes of individual deposits, which generates a sampling bias towards coarser grain sizes overall, nor the subtler differences in grain-size distribution between lobe sub-environments. The fact that almost all samples are slightly skewed towards finer material conforms to the observations Fildani et al. (2018) have reported from the lobes of the Mississippi Fan, that visual descriptions alone tend to overestimate the sand fraction of deposits. These considerations should motivate the research community to increase the integration of microscopic sample analyses into outcrop studies.

\section{1 | Grain-size distribution and sub- environments}

The measured grain-size distributions of the lobe axis, lobe off-axis and lobe fringe are significantly different suggesting that these sub-environments have distinctly different grain-size distributions (Figure 12). Despite the fact that classifications of these sub-environments, based on macroscopic facies characteristics, are transitional, assigning lobe sub-environments to lithofacies associations proved to be a rather powerful method to differentiate the grainsize distributions within the scale of a lobe. Only one sample from the lobe off-axis group strongly differs from the other off-axis samples and is also the coarsest of all the samples. This sample, sample 6 of $\log 2$, was not classified during the macroscopic facies analysis as lobe axis, like the overlying deposits, because an erosional surface above the bed was chosen as lower boundary of the lobe axis at log 2. Based on the grain-size distribution this sample could also be classified as part of the overlying lobe axis. Reassigning individual samples to other sub-environments based on their microscopic grain-size distribution could be justified in practice, but would here generate the appearance of circularity: grain size correlates with facies association, outlying grain-size distributions are re-assigned to another facies association, and therefore also correlate to facies association. Therefore, no such re-interpretations based on the grain size results were made here to illustrate the power of the a priori distinction between subenvironments based on macroscopic facies characteristics.

As discussed in the section about grain-size evaluation methods, the difference in grain size is not related to difference in grain fabric since the deviation due to orientation is much smaller than the deviation between and within the sub-environments. It is assumed that the grain fabric maturity of all samples is similar to the tested sample, implying that the obtained magnitude of difference in grain size with orientation is similar in all samples. This assumption might be invalid as the tested sample is retrieved from a massive turbiditic sandstone. This type of deposit features a broad range of long-axis orientations and possibly results in less variation with orientation compared to structured beds with more mature fabric (Baas et al., 2007). This possible larger difference in orientation is largely eliminated by sampling at the base of the beds, which mostly consist of massive sandstones.

\section{2 | Proximal to distal trend}

The results that are presented in this study strengthen the idea that lobes do not just simply fine from an apex, but show a more complicated non-linear fining trend (Figure 12) and conform to results described from the

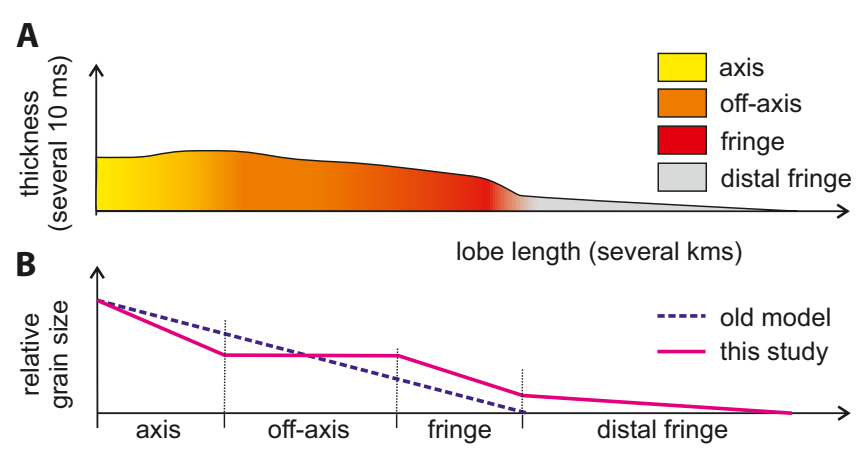

F I G U RE 12 (A) Geometry and general distribution of lobe sub-environments. (B) Longitudinal grain = size evolution of lobe deposits. The old linear model is indicated in a blue dashed line, whereas the non-linear trend suggested by this study is indicated by a pink solid line 
Niger Delta X fan (Jobe et al., 2017), lobes from the Gerbe system (Aínsa Basin, Spain) (Bell et al., 2018) and experimental studies of Fernandez et al. (2014). In this study, lobe axis and fringe settings show a (weak) basinward fining trend, whereas lobe off-axis settings show no longitudinal decrease in grain size (Figure 12). For the Gerbe system down-dip decrease in grain size between lobe axis and offaxis was reported as minimal, whereas a more distinct decrease was documented between lobe off-axis and fringe deposits (Bell et al., 2018). The following section will discuss possible explanations for the observed fining trends.

Generally, there are two fundamental processes that govern deposition from a flow: competence and capacity. The competence of turbidity currents decreases from proximal to distal settings due to the loss in shear velocity, which is directly related to a loss of velocity (Kane et al., 2017; Kneller \& McCaffrey, 2003). This decrease in flow velocity from the lobe apex is caused by the lateral spreading of flow, reduced sediment content due to sedimentation, and/or decreasing slope (Kneller, 1995), and is influenced by the topography of the lobe (Cantelli et al., 2011; Fernandez et al., 2014; Groenenberg et al., 2010; Spychala et al., 2017a). Sediment capacity describes the total amount of sediment a flow is able to transport. If sediment concentration surpasses a flow's capacity deposition is triggered by settling of the excess suspended sediment from the flow (Hiscott, 1994). It is argued that flows that exit the channel mouth are at or near their capacity limit when lobe deposition starts.

One explanation for the decrease in the grain-size profile in the lobe axis combines grain-size stratification of the flow with the transition into lower momentum flows that is associated with the channel-lobe transition zone (Baas et al., 2004; Fildani et al., 2018). Pohl et al. (2019) show that turbidity currents tend to erode upon losing their confinement when passing from a confined channel environment into the unconfined lobe environment. As the flow incorporates more sediment through erosion, capacity-driven sedimentation is invoked (sensu Hiscott, 1994; Kneller \& McCaffrey, 2003; Kubo, 2004). The coarse sediment fraction tends to be concentrated near the base of turbidity currents and is thus preferably deposited, whereas the medium and finer sediment fraction are more homogeneously distributed over the height of the current (Figure 13; de Leeuw et al., 2018a; Eggenhuisen et al., 2020; Garcia, 1994; Hansen et al., 2015; Kneller \& Buckee, 2000; Tilston et al., 2015). Once the base (enriched in coarser grains) of the concentration profile has settled out, the off-axis sediment is deposited from a flow with a relatively homogeneous vertical grain size (Figure 13). Eventually, the flow thins and decreases in density due to continued loss of sediment resulting in the onset of competence-driven deposition in the lobe fringes (Baas et al., 2004; Kneller \& McCaffrey, 2003) creating a second
F I G U RE 13 Observed longitudinal evolution of grain-size distribution from the youngest lobe of Clinothem 12 compared with grain-size concentration profiles for different grain-size classes (after Eggenhuisen et al., 2020)

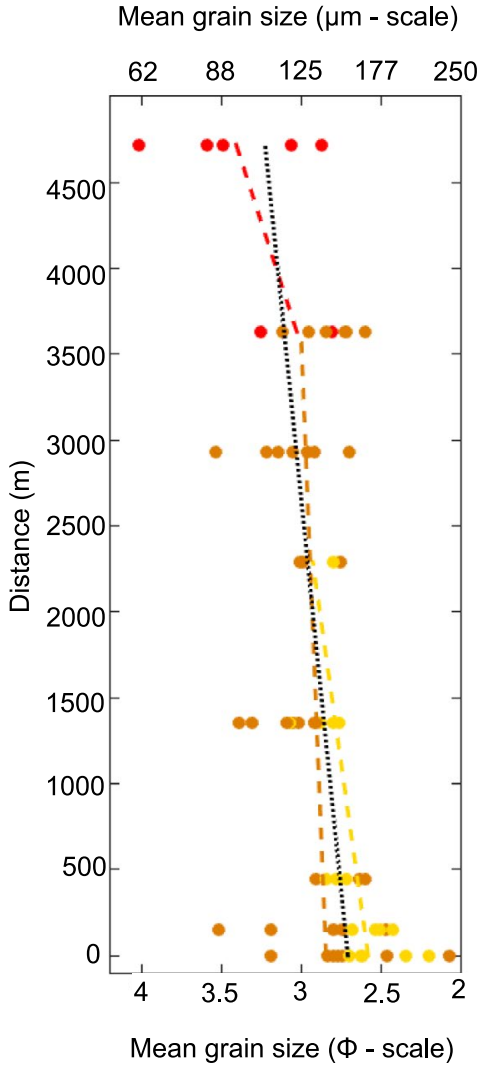


fining trend. This probably goes hand in hand with the deposition of most of the remaining sand grains, creating the sand pinch-out described from field observations of the lobe fringe (Prélat et al., 2009; Spychala et al., 2017a) long before the silt pinch-out in the distal fringe (Spychala et al., 2020). This evolution of the flow as it deposits sediment on its journey across a lobe would overall result in fining from the lobe axis to the intermediate and distal areas of the lobe off-axis and lobe fringe, which conforms to the trend seen in the deposits of Clinothem 12.

Grain-size stratification has previously been widely used to explain grain size trends in submarine channel and canyon systems (de Leeuw et al., 2018a, 2018b; Hansen et al., 2015; Hiscott et al., 1997; Hubbard et al., 2014; Jobe et al., 2017; Pirmez \& Imran, 2003), but was so far not taken into consideration as an explanation of fining trends in lobe deposits. This study suggests that proximal to distal fining of lobe deposits is essentially the result of grain-size stratification in the flow exiting the channel, and the advection length of the different grain sizes (Boulesteix et al., 2020; Ganti et al., 2014; Spychala et al., 2020). The results of this study can be used to help the distribution of grain sizes in already existing simplified modelling approaches (Burgess et al., 2019; Pyrcz et al., 2005). The Clinothem 12 lobe deposits documented in this study may serve as a testing ground for such models (please refer to grain-size files in Material S1).

\subsection{Explaining the spread in lobe fringe samples}

Lobe fringe samples collected from Log HS (Hyrnestabben, Figures 1C and 2) show a wide spread in mean grain sizes ranging from silt to fine sand (4.03 $\phi$ to $2.75 \phi)$. It is noteworthy that the samples at this location were collected from lithofacies that are interpreted as being deposited by two different types of sediment gravity flows: turbidity currents and transitional flows. Samples from beds that are taken from turbidites are finer and better sorted than those taken from hybrid beds (Figure 8C,D) and their deposition is controlled by different flow processes. These differences in flow processes likely also cause a positive skew of grain-size distributions within turbidites, whereas hybrid beds are more likely to show a negative skew, especially in their lower division (Kane et al., 2017) enhancing the difference in grain size further. In contrast, Fildani et al. (2018) propose that hybrid beds from the Mississippi fan have a significant larger portion of silt and finer grains than the observed turbidites or can even be observed to be bimodal. Hybrid beds have been described to be deposited by several flow processes: Longitudinal evolution from a turbidity current (sensu Haughton et al., 2003) and vertical segregation in supersaturated flows (sensu Baas et al., 2009; Kane et al., 2017). Whether differences in grain-size distribution can reflect the exact process is speculative at this point. However, neither of these characteristics are seen in the limited dataset of samples collected from hybrid beds. Deposits from a purely turbiditic succession would show a stronger fining trend, which is now dampened by the data from the hybrid bed deposits. It is clear that more work has to be conducted to study this longitudinal grain-size differentiation between the two flow types.

\section{4 | Expression of stacking patterns in grain-size data}

Lobe stacking patterns like progradation and retrogradation may skew the longitudinal grain-size distribution trend seen. While progradation would probably push the extent of coarse grain sizes further into the basin, retrogradation would cause a grain-size trend to finer material. In this case, there is no major influence of progradational or retrogradational stacking patterns in the evaluated grain-size distributions for the youngest lobe of Clinothem 12. Neither vertical grain-size distribution (Figure 11) nor bed thickness plots (Figure 14) for the individual logs show a clear coarsening and thickening upward trend, nor the fining and thinning upward trend which would be characteristic of progradation and retrogradation, respectively. This conforms with the observations made from by Prélat and Hodgson (2013) who suggest that lobes can show a full range of bed thickness patterns. The data given here support that this is true for different log sections of the same lobe deposit and indicates that the stacking patterns of the studied lobe are primarily governed by compensational stacking.

However, it is likely that the influence of stacking patterns would become more apparent if grain-size distributions for lobe complexes that comprise several lobes were analysed. Further work in a well reconstructed lobe complex example is necessary to assess this question.

\section{5 | Implications for hydrocarbon reservoir quality}

This study aims to understand how the spatial evolution of turbidity currents is recorded in lobe deposits on a scale of approximately $5 \mathrm{~km}$. The results have implications for kilometre-scale distribution of hydrocarbon reservoir parameters, as grain size is a main factor control on reservoir quality (Bell et al., 2018; Ghaffar et al., 2017; Porten et al., 2016). The amalgamated structureless sandstones that characterise lobe-axis settings have been interpreted as high-density turbidity current deposits (Bell et al., 2018; 

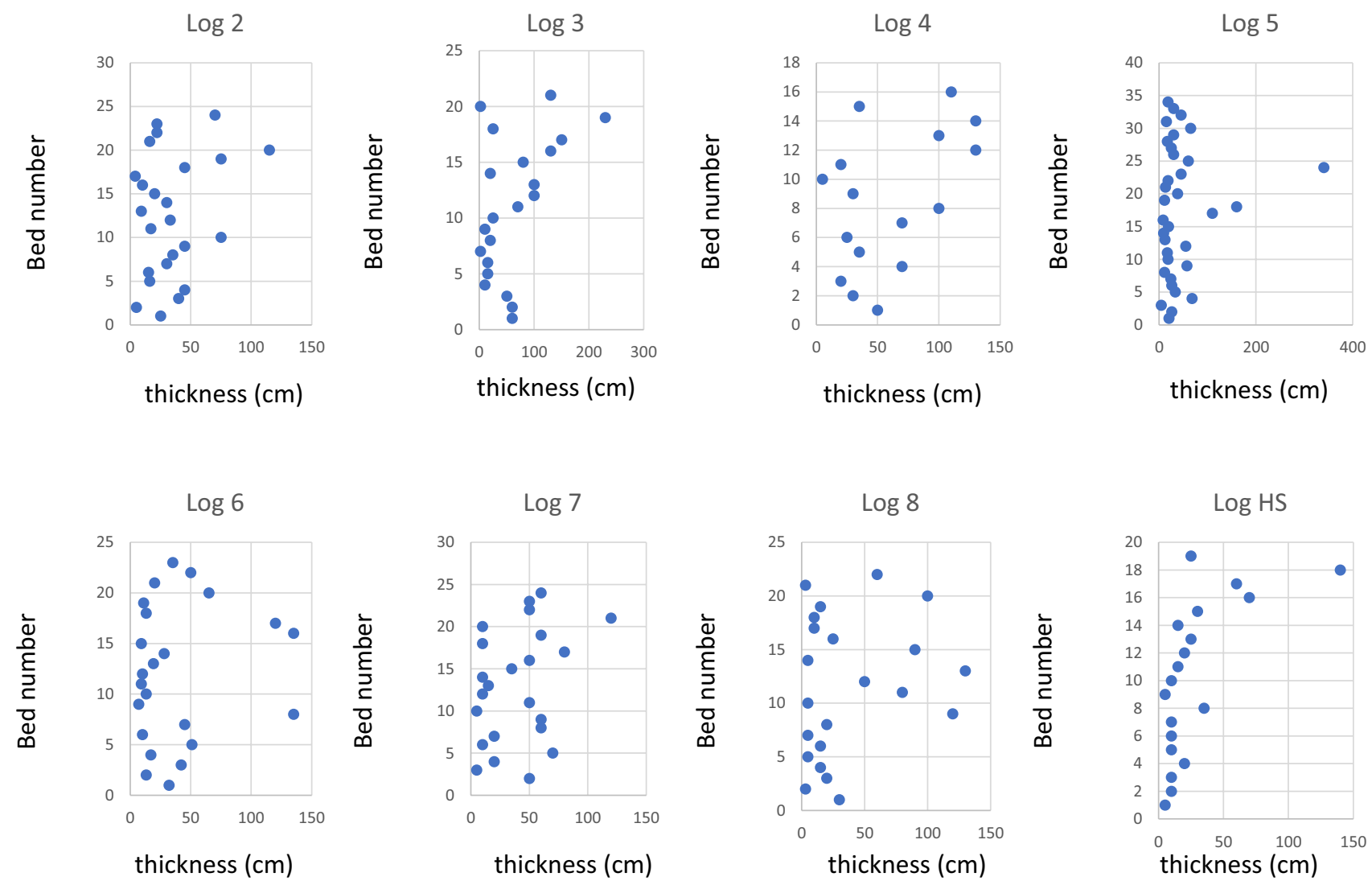

F I G U R E 14 Vertical bed thickness distribution for the individual logs of Clinothem 12. Note: Horizontal axis for log 3, log 5 and log HS deviate from the other logs

Grundvåg et al., 2014b; Prélat et al., 2009; Spychala et al., 2017a). Generally, these deposits are associated with the best reservoir characteristics as they are (a) commonly low on clay content which is connected to the highest permeabilities, and (b) have been suggested to have higher permeability because of their coarse grain size (Ghaffar et al., 2017; Porten et al., 2016). Ghaffar et al. (2017) report that permeability can decrease by at least $50 \%$ when grain size transitions from medium to fine sand. Lobe off-axes are characterised by sediments that are deposited from highdensity turbidity currents as well as from low-density turbidity currents. Bell et al. (2018) did not observe a significant change in sorting between lobe axis and off-axis, which conforms to observations from this study. However, besides finer grain size, the lobe off-axis is associated with an increase in matrix content which decreases permeability (Bell et al., 2018). Lobe fringe deposits comprise finegrained deposits from low-density turbidity currents and deposits that were deposited by flows that show turbulent as well as laminar behaviour (hybrid beds). Low-density turbidites are associated with the finest grain sizes, highest matrix content and lowest net: gross. The results of this study suggest that reservoir quality changes with distance most strongly within lobe axis and lobe fringe, albeit in the case of lobe axis deposits the chance is from very high quality to high quality. The reservoir quality of lobe offaxis deposits is demonstrated to be homogeneous without proximal to distal trends. This outcome has two implications: (a) It is justified to model lobes as high-quality reservoirs elements right until their transition to lobe fringes; and (b) Reservoir quality can be uncoupled from reservoir thickness as the intermediate lobe deposits show thinning without a change in depositional sand quality. These outcomes can augment stochastic lobe modelling approaches (Pyrcz et al., 2005) by adding the additional factor of grainsize trends to the model.

\section{5 | CONCLUSIONS}

The basin-floor fans of the Battfjellet Formation in Svalbard that outcrop in a proximal to distal orientation create the rare opportunity to analyse the longitudinal evolution of these distal deposits from lobe axis to fringe over a distance of $5 \mathrm{~km}$. Within the investigated basin floor segment of Clinothem 12, lobe sub-environments have been distinguished based on their characteristic lithofacies associations and bounding surfaces, which 
reflect depositional flow properties. A transition from predominantly high-density turbidity current deposits to low-density turbidity current deposits and hybrid beds is observed. A total of 66 photographed thin sections were manually counted to determine the grain-size distribution of lobe axis, lobe off-axis and lobe-fringe deposits. These sub-environments have statistically distinct and variable grain-size distributions superimposed on an overall non-linear fining trend from lobe axis to lobe fringe. Only a single sample yielded grain-size results that could justify re-assignment of the macroscopic facies association that was ascribed a priori the thin section analysis. This success rate reinforces the confidence in established facies classification schemes for lobe deposits. Furthermore, the sub-environments show different longitudinal grain-size trends. Lobe axis and fringe settings show (weak) basinward fining trends whereas lobe off-axis settings show no variation in grain-size distribution with distance. An explanation for these trends is the interplay of capacity-driven deposition from the decelerating flow, the grain-size stratification of the flows, and advection of the flow over the lobe. Overall, the coarser grain-size fraction is enriched at the base of the flow and more prone to be deposited when capacity-driven deposition is evoked in the lobe axis. The lobe off-axis is suggested to be deposited from the more homogeneously mixed part of the flow, whereas the lobe fringe is dominated by deposition of the upper parts of the flow, resulting in the sand pinch-out in the lobe fringe.

The implications of this study are multifaceted: (a) Grain-size stratification is an important factor in the evolution and deposition of turbidity currents over lobe deposits and may be incorporated into modelling approaches of lobe deposits; (b) it is justified to model lobes as high-quality bodies until their transition to lobe fringes; and (c) reservoir quality can be uncoupled from reservoir thickness as the intermediate lobe deposits show thinning but no change in depositional sand quality.

\section{ACKNOWLEDGEMENTS}

This project was funded by NWO (grant \# NWO-ALWVidi-864.13.006), ExxonMobil, Shell Exxon Mobil Corporation, and Equinor for which we are thankful. Sten-Andreas Grundvåg received funding from the ARCEx project (Research Centre for Arctic Petroleum Exploration), which is funded by the Research Council of Norway (grant number 228107). Furthermore, we would like to thank Captain Stig Henningsen of the MS Farm. We would also like to thank Elisabeth Steel and Zane Jobe for their helpful and constructive reviews which have enabled us to clarify and improve the manuscript.

\section{DATA AVAILABILITY STATEMENT}

All raw grain size data are in the supporting materials. For any additional information feel free to contact the corresponding author who is happy to share these with you.

\section{ORCID}

Yvonne T. Spychala (D) https://orcid.

org/0000-0002-3896-9234

Joris T. Eggenhuisen (D) https://orcid.

org/0000-0002-7389-9665

\section{REFERENCES}

Allen, J.R.L. (1971) Instantaneous sediment deposition rates deduced from climbing-ripple cross-lamination. Journal of Geological Society London, 127, 553-561.

Allen, J.R.L. (1973) A classification of climbing-ripple crosslamination. Journal of the Geological Society London, 129, 537-541.

Allen, J.R.L. (1982) Sedimentary structures: their character and physical basis, vol. 1,2. Amsterdam: Elsevier, pp. 593-663.

Arnott, R.W.C. \& Hand, B.C. (1989) Bedforms, primary structures and grain fabric in the presence of suspended sediment rain. Journal of Sedimentary Petrology, 59, 1062-1069.

Baas, J.H., Best, J.L., Peakall, J. \& Wang, M. (2009) A phase diagram for turbulent, transitional, and laminar clay suspension flows. Journal of Sedimentary Research, 79, 162-183.

Baas, J.H., Hailwood, E.A., McCaffrey, M.D., Kay, M. \& Jones, R. (2007) Directional petrological characterisation of deepmarine sandstones using grain fabric and permeability anisotropy. Methodologies, Theory, Application and Suggestions for Integration, Earth-Science Reviews, 82, 101-142.

Baas, J.H., Van Kesteren, W. \& Postma, G. (2004) Deposits of depletive high-density turbidity currents: a flume analogue of bed geometry, structure and texture. Sedimentology, 51, 1053-1088.

Bell, D., Kane, I.A., Pontén, A.S., Flint, S.S., Hodgson, D.M. \& Barrett, B.J. (2018) Spatial variability in depositional reservoir quality of deep-water channel-fill and lobe deposits. Marine and Petroleum Geology, 98, 97-115.

Bergh, S.G., Braathen, A. \& Andresen, A. (1997) Interaction of basement-involved and thin-skinned tectonism in the Tertiary fold-thrust belt of central Spitsbergen, Svalbard. AAPG Bulletin, 81(4), 637-661.

Boulesteix, K., Poyatos-Moré, M., Hodgson, D.M., Flint, S.S. \& Taylor, K.G. (2020) Fringe or background: characterizing deep-water mudstones beyond the basin-floor fan sandstone pinchout. Journal of Sedimentary Geology, 90, 1678-1705.

Bouma, A.H. (1962) Sedimentology of some flysch deposits: a graphic approach to facies interpretation. Amsterdam: Elsevier, $168 \mathrm{pp}$.

Bouma, A.H. (2000) Fine-grained, mud-rich turbidite systems: model and comparison with coarse-grained, sand-rich systems. In: Bouma, A.H. and Stone, C.G. (Eds.), Fine-grained turbidite systems. . AAPG Memoir 72/SEPM Special Publications, 68, 9-19.

Braathen, A. \& Bergh, S.G. (1995) Kinematics of Tertiary deformation in the basement-involved fold-thrust belt, western Nordenskiold Land, Svalbard: tectonic implications based on fault slip data analysis. Tectonophysics, 249, 1-29.

Bruhn, R. \& Steel, R. (2003) High-resolution sequence stratigraphy of a clastic foredeep succession (Paleocene, Spitsbergen): an 
example of peripheral-bulge-controlled depositional architecture. Journal of Sedimentary Research, 73, 745-755.

Burdige, D.J. (2005) Burial of terrestrial organic matter in marine sediments: a re-assessment. Global Biogeochemical Cycles, 19, GB4011.

Burgess, P., Masiero, I., Toby, S.C. \& Duller, R.A. (2019) A big fan of signals? Exploring autogenic and allogenic process and product in a numerical stratigraphic forward model of submarine-fan development. Journal of Sedimentary Research, 89, 1-12.

Cantelli, A., Pirmez, C., Johnson, S. \& Parker, G. (2011) Morphodynamic and stratigraphic evolution of selfchannelized subaqueous fans emplaced by turbidity currents. Journal of Sedimentary Research, 81, 233-247.

Clark, B.E. \& Steel, R. (2006) Eocene turbidite-population statistics from shelf edge to basin floor, Spitsbergen, Svalbard. Journal of Sedimentary Research, 76, 903-918.

Crabaugh, J.P. \& Steel, R.J. (2004) Basin-floor fans of the Central Tertiary Basin, Spitsbergen: relationship of basinfloor sandbodies to prograding clinoforms in a structurally active basin. In: Lomas, S.A. \& Joseph, P. (Eds.) Confined turbidite systems. Geological Society of London Special Publications, 222, 187-208.

De Leeuw, J. (2017) The sedimentary record of submarine channel morphodynamics. PhD Thesis, Utrecht University.

de Leeuw, J., Eggenhuisen, J.T. \& Cartigny, M.J.B. (2018a) Linking submarine channel-levee facies and architecture to flow structure of turbidity currents: insights from flume tank experiments. Sedimentology, 65, 931-951.

de Leeuw, J., Eggenhuisen, J.T., Spychala, Y.T., Heijnen, M.S., Pohl, F. \& Cartigny, M.J.B. (2018b) Sediment volume and grain-size partitioning between submarine channel-levee systems and lobes: an experimental study. Journal of Sedimentary Research, $88,1-18$.

Deptuck, M.E., Piper, D.J., Savoye, B. \& Gervais, A. (2008) Dimensions and architecture of late Pleistocene submarine lobes off the northern margin of East Corsica. Sedimentology, 55(4), 869-898.

Eggenhuisen, J.T., Tilston, M.C., de Leeuw, J., Pohl, F. \& Cartigny, M.J.B. (2020) Turbulent diffusion modelling od sediment in turbidity currents: an experimental validation of the Rouse approach. Depositional Record, 6, 203-216.

Etienne, S., Mulder, T., Bez, M., Desaubliaux, G., Kwasniewski, A., Parize, O., Dujoncquoy, E. \& Salles, T. (2012) Multiple scale characterization of sand-rich distal lobe deposit variability: examples from the Annot Sandstones Formation, EoceneOligocene, SE France. Sedimentary Geology, 273-274, 1-18.

Fernandez, R.L., Cantelli, A., Pirmez, C., Sequeiros, O. \& Parker, G. (2014) Growth patterns of subaqueous depositional channel lobe systems developed over a basement with a down-dip break in slope: laboratory experiments. Journal of Sedimentary Research, 84, 168-182.

Fildani, A., Clark, J., Covault, J.A., Power, B., Romans, B.W. \& Aiello, I.W. (2018) Muddy sand and sandy mud on the distal Mississippi fan: implications for lobe depositional processes. Geosphere, 14, 1051-1066.

Ganti, V., Lamb, M.P. \& McElroy, B. (2014) Quantitative bounds on morphodynamics and implications for reading the sedimentary record. Nature Communications, 5, 3298.

Garcia, M.H. (1994) Depositional turbidity currents laden with poorly sorted sediment. Journal of Hydraulic Engineering, 120, $1240-1263$.
Ghaffar, H.A., Prasetyo, T., Stanbrook, D.A., Henderson, G. \& Sarginson, M. (2017) Reservoir properties of proximal to distal turbidites-deep-water Sabah, Malaysia. In: Asia Petroleum Geoscience Conference and Exhibition (APGCE) 2017. Kuala Lumpur, Malaysia, pp. 147-150.

Groenenberg, R.M., Hodgson, D.M., Prélat, A., Luthi, S.M. \& Flint, S.S. (2010) Flow-deposit interaction in submarine lobes: insights from outcrop observations and realizations of a processbased numerical model. Journal of Sedimentary Research, 80, 252-267.

Grundvåg, S.-A., Helland-Hansen, W., Johannessen, E.P., Olsen, A.H. \& Stene, S.A.K. (2014a) The depositional architecture and facies variability of shelf deltas in the Eocene Battfjellet Formation, Nathorst Land, Spitsbergen. Sedimentology, 61, 2172-2204.

Grundvåg, S.-A., Johannessen, E.P., Helland-Hansen, W. \& PlinkBjörklund, P. (2014b) Depositional architecture and evolution of progradationally stacked lobe complexes in the Eocene Central Basin of Spitsbergen. Sedimentology, 61, 535-569. https://doi.org/10.1111/sed.12067

Hansen, L.A.S., Callow, R.H.T., Kane, I.A., Gamberi, F., Rovere, M., Cronin, B.T. \& Kneller, B. (2015) Genesis and character of thinbedded turbidites associated with submarine channels. Marine and Petroleum Geology, 67, 852-879.

Haremo, P., Andresen, A. \& Dypvik, H. (1993) Mesozoic extension versus Tertiary compression along the Billefjorden Fault Zone south of Isfjorden, central Spitsbergen. Geological Magazine, 130(6), 783-795.

Haughton, P.D. (1994) Deposits of deflected and ponded turbidity currents, Sorbas Basin, Southeast Spain. Journal of Sedimentary Research, 64(2a), 233-246.

Haughton, P.D.W., Barker, S.P. \& McCaffrey, W.D. (2003) 'Linked' debrites in sand-rich turbidite systems - origin and significance. Sedimentology, 50, 459-482.

Haughton, P., Davis, C., McCaffrey, W. \& Barker, S. (2009) Hybrid sediment gravity flow deposits - classification, origin and significance. Marine and Petroleum Geology, 26, 1900-1918.

Hedges, J.I., Keil, R.G. \& Benner, R. (1997) What happens to terrestrial organic matter in the ocean? Organic Geochemistry, 71, 195-212.

Helland-Hansen, W. (1990) Sedimentation in Paleogene foreland basin, Spitsbergen. AAPG Bulletin, 74, 260-272.

Helland-Hansen, W. (1992) Geometry and facies of Tertiary clinothems, Spitsbergen. Sedimentology, 39, 1013-1029.

Helland-Hansen, W. \& Grundvåg, S.-A. (2021) The Svalbard EoceneOligocene (?) Central Basin succession: sedimentation patterns and controls. Basin Research, 33, 729-753.

Hiscott, R.N. (1994) Loss of capacity, not competence, as the fundamental process governing deposition from turbidity currents. Journal of Sedimentary Research, 64, 209-214.

Hiscott, R.N., Hall, F.R. \& Pirmez, C. (1997) Turbidity-current overspill from the Amazon channel: texture of the silt/sand load, paleoflow from anisotropy of magnetic susceptibility and implications for flow processes. Proceedings of the Ocean Drilling Program, Scientific Results, 155, 53-78.

Hiscott, R.N. \& Middleton, G.V. (1980) Fabric of coarse deep-water sandstones, Tourelle Formation, Quebec, Canada. Journal of Sedimentary Research, 50(3), 703-721.

Hubbard, S.M., Covault, J.A., Fildani, A. \& Romans, B.W. (2014) Sediment transfer and deposition in slope channels: 
deciphering the record of enigmatic deep-sea processes from outcrop. Geological Society of America, Bulletin, 126, 857-871.

Hunter, R.E. (1977) Terminology of cross-stratified sedimentary layers and climbing-ripple structures. Journal of Sedimentary Research, 47, 697-706.

Jobe, Z., Sylvester, Z., Pittaluga, M.B., Frascati, A., Pirmez, C., Minisini, D., Howes, N. \& Cantelli, A. (2017) Facies architecture of submarine channel deposits on the western Niger Delta slope: implications for grain-size and density stratification in turbidity currents. Journal of Geophysical Research. Earth Surface, 122, 473-491.

Johannessen, E.P. \& Steel, R.J. (2005) Shelf-margin clinoforms and prediction of deepwater sands. Basin Research, 17, 521-550.

Jopling, A.V. \& Walker, R.G. (1968) Morphology and origin of rippledrift cross-lamination, with examples from the Pleistocene of Massachusetts. Journal of Sedimentary Research, 38, 971-984.

Kane, I.A. \& Clare, M.A. (2019) Dispersion, accumulation, and the ultimate fate of microplastics in deep-marine environments: a review and future directions. Frontiers in Earth Science, 7, 80. https://doi.org/10.3389/feart.2019.00080

Jobe, Z.R., Lowe, D.R. \& Morris, W.R. (2012) Climbing-ripple successions in turbidite systems: depositional environments, sedimentation rates and accumulation times. Sedimentology, 59, 867-898.

Johnson, M.R. (1994) Thin section grain size analysis revisited. Sedimentology, 41(5), 985-999.

Kane, I.A., Pontén, A.S., Vangdal, B., Eggenhuisen, J.T., Hodgson, D.M. \& Spychala, Y.T. (2017) The stratigraphic record and processes of turbidity current transformation across deep-marine lobes. Sedimentology, 64(5), 1236-1273.

Kellogg, H.E. (1975) Tertiary stratigraphy and tectonism in Svalbard and continental drift. American Association of Petroleum Geologists Bulletin, 59, 465-485.

Kneller, B. (1995) Beyond the turbidite paradigm: physical models for deposition of turbidites and their implications for reservoir prediction. In: Hartley, A.J. (Ed.), Characterization of deep marine clastic systems. Geological Society of London, Special Publication 94, 31-49.

Kneller, B.C. \& Branney, M.J. (1995) Sustained high-density turbidity currents and the deposition of thick massive sands. Sedimentology, 42, 607-616.

Kneller, B. \& Buckee, C. (2000) The structure and fluid mechanics of turbidity currents: a review of some recent studies and their geological implications. Sedimentology, 47, 62-94.

Kneller, B., Edwards, D., McCaffrey, W. \& Moore, R. (1991) Oblique reflection of turbidity currents. Geology, 19(3), 250-252.

Kneller, B. \& McCaffrey, W. (1999) Depositional effects of flow nonuniformity and stratification within turbidity currents approaching a bounding slope; deflection, reflection and facies variation. Journal of Sedimentary Research, 69, 980-991.

Kneller, B.C. \& McCaffrey, W.D. (2003) The interpretation of vertical sequences in turbidite beds: the influence of longitudinal flow structure. Journal of Sedimentary Research, 73, 706-713. https://doi.org/10.1306/031103730706

Krumbein, W.C. (1934) Size frequency distributions of sediments. Journal of Sedimentary Research, 4(2), 65-77.

Kubo, Y. (2004) Experimental and numerical study of topographic effects on deposition from two-dimensional, particle-driven density currents. Sedimentary Geology, 164, 311-326.
Leclair, S.F. \& Arnott, R.W.C. (2005) Parallel lamination formed by high-density turbidity currents. Journal of Sedimentary Research, 75, 1-5.

Leever, K.A., Gabrielsen, R.H., Faleide, J.I. \& Braathen, A. (2011) A transpressional origin for the West Spitsbergen fold-and-thrust belt: insight from analog modeling. Tectonics, 30(2), 1-24.

Lundin, E. \& Doré, A. (2002) Mid-Cenozoic post-breakup deformation in the 'passive' margins bordering the NorwegianGreenland Sea. Marine and Petroleum Geology, 19, 79-93.

Marchand, A.M.E., Apps, G., Li, W. \& Rotzien, J.R. (2015) Depositional processes and impact on reservoir quality in deepwater Paleogene reservoirs, US Gulf of Mexico. American Association of Petroleum Geologists, Bulletin, 99, 1635-1648.

Masalimova, L.U., Lowe, D.R., Sharman, G.R., King, P.R. \& Arnot, M.J. (2016) Outcrop characterization of a submarine channellobe complex: the Lower Mount Messenger Formation, Taranaki Basin, New Zealand. Marine and Petroleum Geology, 71, 360-390.

Mellere, D., Plink-Björklund, P. \& Steel, R.J. (2002) Anatomy of shelf deltas at the edge of a prograding Eocene shelf margin, Spitsbergen. Sedimentology, 49, 1181-1206.

Müller, R.D. \& Spielhagen, R.F. (1990) Evolution of the Central Tertiary Basin of Spitsbergen: towards a synthesis of sediment and plate tectonic history. Palaeogeography, Palaeoclimatology, Palaeoecology, 80, 153-172.

Mutti, E. (1992) Turbidite sandstones. Italy: Instituto di Geologia, Università di Parma \& AGIP, San Donato Milanese, 275 pp.

Myhre, A.M., Eldholm, O. \& Sundvor, E. (1982) The margin between Senja and Spitsbergen fracture zones: implications from plate tectonics. Tectonophysics, 89(1-3), 33-50.

Paola, C. \& Martin, J.M. (2012) Mass-balance effects in depositional systems. Journal of Sedimentary Research, 82, 435-450.

Petersen, T.G., Thomsen, T., Olaussen, S. \& Stemmerik, L. (2016) Provenance shifts in an evolving Eurekan foreland basin: the Tertiary Central Basin, Spitsbergen. Journal of the Geological Society, 173, 634-648.

Piepjohn, K., von Gosen, W. \& Tessensohn, F. (2016) The Eurekan deformation in the Arctic: an outline. Journal of the Geological Society, 173, 1007-1024.

Pirmez, C. \& Imran, J. (2003) Reconstruction of turbidity currents in the Amazon Channel. Marine and Petroleum Geology, 20, 823-849.

Plink-Björklund, P., Mellere, D. \& Steel, R.J. (2001) Turbidite variability and architecture of sand-prone, deepwater slopes: eocene clinoforms in the Central Basin, Spitsbergen. Journal of Sedimentary Research, 71, 895-912.

Pohl, F., Eggehuisen, J.T., Kane, I.A. \& Clare, M.A. (2020) Transport and burial of microplastics in deep-marine sediments by turbidity currents. Environmental Science and Technology, 54(7), 4180-4189.

Pohl, F., Eggehuisen, J.T., Tilston, M. \& Cartigny, M.J.B. (2019) New flow relaxation mechanism explains scour field at the end of submarine channels. Nature Communications, 10, 4425. https://doi.org/10.1038/s41467-019-12389-x

Pohl, F. \& McCann, T. (2014) Architecture and depositional development of the Eocene deep-marine Morillo and Coscojuela Formations, Aínsa Basin, Spain. Geological Journal, 49(3), 221-238.

Porten, K.W., Kane, I.A., Warchoł, M.J. \& Southern, S.J. (2016) A sedimentological process-based approach to depositional 
reservoir quality of deep-marine sandstones: an example from the Springar Formation, northwestern Vøring Basin, Norwegian Sea. Journal of Sedimentary Research, 86(11), 1269-1286.

Prather, B.E., O'Byrne, C., Pirmez, C. \& Sylvester, Z. (2017) Sediment partitioning, continental slopes and base-of-slope systems. Basin Research, 29(3), 394-416.

Prélat, A., Covault, J.A., Hodgson, D.M., Fildani, A. \& Flint, S.S. (2010) Intrinsic controls on the range of volumes, morphologies, and dimensions of submarine lobes. Sedimentary Geology, $232,66-76$.

Prélat, A. \& Hodgson, D.M. (2013) The full range of turbidite bed thickness patterns in submarine lobes: controls and implications. Geological Society of London, 170, 1-6.

Prélat, A., Hodgson, D. \& Flint, S. (2009) Evolution, architecture and hierarchy of distributary deep-water deposits: a high-resolution outcrop investigation from the Permian Karoo Basin, South Africa. Sedimentology, 56, 2132-2154.

Prycz, M.J., Catuneau, O. \& Deutsch, C.V. (2005) Stochatstic surfacebased modeling of turbidite lobes. AAPG Bulletin, 89, 177-191.

Reading, H.R. \& Richards, M. (1994) Turbidite systems in deepwater basin margins classified by grain size and feeder system. AAPG Bulletin, 78(5), 792-822. https://doi.org/10.1306/A25FE 3BF-171B-11D7-8645000102C1865D

Spotts, J.H. (1964) Grain orientation and imbrication in Miocene turbidity current sandstones, California. Journal of Sedimentary Research, 34(2), 229-253.

Spychala, Y.T., Eggenhuisen, J.T., Tilston, M. \& Pohl, F. (2020) The influence of basin setting and turbidity current properties on the dimensions of submarine lobe elements. Sedimentology, 67(7), 3471. https://doi.org/10.1111/sed.12751

Spychala, Y.T., Hodgson, D.M., Flint, S.S. \& Mountney, N.P. (2015) Constraining the sedimentology and stratigraphy of submarine intraslope lobe deposits using exhumed examples from the Karoo Basin, South Africa. Sedimentary Geology, 322, 67-81.

Spychala, Y.T., Hodgson, D.M. \& Lee, D.R. (2017b) Autogenic controls on hybrid bed distribution in submarine lobe complexes. Marine and Petroleum Geology, 88, 1078-1093.

Spychala, Y.T., Hodgson, D.M., Prélat, A., Kane, I.A., Flint, S.S. \& Mountney, N.P. (2017a) Frontal and lateral submarine lobe fringes: comparing sedimentary facies, architecture and flow processes. Journal of Sedimentary Research, 87(1), 75-96.

Southard, J.B. (1991) Experimental determination of bed-form stability. Annual Review of Earth and Planetary Science, 19, 423-455.

Steel, R., Dalland, A., Kalgraff, K. \& Larsen, V. (1981) The Central Tertiary Basin of Spitsbergen: sedimentary development of a Sheared-Margin Basin. In: Kerr, J.W. \& Ferguson, A.J. (Eds.) Geology of the North Atlantic Borderland. Canadian Society of Petroleum Geologist Memoirs, 7, 647-664.

Steel, R., Gjelberg, J., Helland-Hansen, W., Kleinspehn, K., Nøttvedt, A. \& Rye-Larsen, M. (1985) The Tertiary strike-slip basins and orogenic belt of Spitsbergen. SEPM Special Publication, 37, 339-359.

Steel, R.J. \& Olsen, T. (2002) Clinoforms, clinoform trajectories and deepwater sands. In: Armentrout, M. \& Rosen, N.C. (Eds.)
Sequence stratigraphic models for exploration and production: evolving methodology, emerging models and application histories. GCS-SEPM Found 22nd Annual Research Conference Proceedings, pp. 367-381 (CD-ROM).

Stow, D.A.V. \& Piper, D.J.W. (1984). Deep-water fine-grained sediments: facies models. In Stow, D.A.V. \& Piper, D.J.W. (Eds.), Fine-grained sediments: deep-water processes and facies. Geological Society of London, Special Publication, 15, 611-646.

Straub, K.M., Mohrig, D. \& Pirmez, C. (2012) Architecture of an aggradational tributary submarine channel network on the continental slope offshore Brunei Darussalam. In: Prather, B.E., Deptuck, M.E., Mohrig, D.C., van Hoorn, B. \& Wynn, R.B. (Eds.) Application of the principles of seismic geomorphology to continental-slope and base-of-slope systems: case studies from seafloor and near-seafloor analogues. SEPM Special Publication, 99, 145-161.

Sumner, E.J., Amy, L.A. \& Talling, P.J. (2008) Deposit structure and processes of sand deposition from decelerating sediment suspensions. Journal of Sedimentary Research, 78(8), 529-547. https://doi.org/10.2110/jsr.2008.062

Sylvester, Z. \& Lowe, D.R. (2004) Textural trends in turbidites and slurry beds from the Oligocene flysch of the East Carpathians, Romania. Sedimentology, 51(5), 945-972.

Talling, P.J., Amy, L.A., Wynn, R.B., Peakall, J. \& Robinson, M. (2004) Beds comprising debrite sandwiched within co-genetic turbidite: origin and widespread occurrence in distal depositional environments. Sedimentology, 51, 163-194.

Talling, P.J., Masson, D.G., Sumner, E.J. \& Malgesini, G. (2012) Subaqueous sediment density flows: depositional processes and deposit types. Sedimentology, 59, 1937-2003.

Tilston, M., Arnott, R.W.C., Rennie, C.D. \& Long, B. (2015) The influence of grain size on the velocity and sediment concentration profiles and depositional record of turbidity currents. Geology, 43, 839-842.

van der Merwe, W.C., Hodgson, D.M., Brunt, R.L., \& Flint, A.S. (2014) Depositional architecture of sand-attached and sand-detached channel-lobe transition zones on an exhumed stepped slope mapped over a $2500 \mathrm{~km}^{2}$ area. Geosphere, 10, 1076-1093.

\section{SUPPORTING INFORMATION}

Additional supporting information may be found in the online version of the article at the publisher's website.

How to cite this article: Spychala, Y.T., Ramaaker, T.A.B., Eggenhuisen, J.T., Grundvåg, S.-A., Pohl, F. \& Wróblewska, S. (2021) Proximal to distal grain-size distribution of basin-floor lobes: A study from the Battfjellet Formation, Central Tertiary Basin, Svalbard. The Depositional Record, 00, 1-21. https://doi.org/10.1002/dep2.167 